Research Article

\title{
Functionalised Au Coated Iron Oxide Nanocomposites Based Reusable Immunosensor for AFB1 Detection
}

\author{
Ruchika Chauhan and T. Basu \\ Amity Institute of Nanotechnology, Amity University, Uttar Pradesh, Noida 201301, India \\ Correspondence should be addressed to T. Basu; basu002@yahoo.com
}

Received 17 March 2015; Accepted 14 June 2015

Academic Editor: Tapan Desai

Copyright (C) 2015 R. Chauhan and T. Basu. This is an open access article distributed under the Creative Commons Attribution License, which permits unrestricted use, distribution, and reproduction in any medium, provided the original work is properly cited.

\begin{abstract}
A reusable sandwiched electrochemical piezoelectric immunosensor has been developed for aflatoxin B1 (AFB1) detection using gold coated iron oxide core-shell $\left(\mathrm{Au}-\mathrm{Fe}_{3} \mathrm{O}_{4}\right)$ nanostructure. The monoclonal anti-aflatoxin antibody (aAFB1) was immobilized on self-assembled monolayer of 4-aminothiophenol on gold coated quartz crystal to fabricate immunoelectrode (BSA/aAFB1/4$\mathrm{ATP} / \mathrm{Au}$ ). In addition, secondary rabbit-immunoglobulin antibodies (r-IgGs) functionalized with $\mathrm{Au}-\mathrm{Fe}_{3} \mathrm{O}_{4} \mathrm{NPs}_{\text {via cysteamine }}$ ( $\mathrm{r}-\mathrm{IgG}-\mathrm{Cys}-\mathrm{Au}-\mathrm{Fe}_{3} \mathrm{O}_{4}$ ) were allowed to interact with AFB1. Both competitive and noncompetitive strategies were employed and a competition between coated AFB1 and free AFB1 was carried out. The competitive mode shows higher linear range (0.05 to $\left.5 \mathrm{ng} \mathrm{mL}^{-1}\right)$ than the noncompetitive one $\left(0.5\right.$ to $\left.5 \mathrm{ng} \mathrm{mL}^{-1}\right)$, high sensitivity $335.7 \mu \mathrm{Ang}^{-1} \mathrm{~mL} \mathrm{~cm}^{-2}$, and LOD $0.07 \mathrm{ng} \mathrm{mL}$. The fabricated immunosensor has been tested using cereal samples spiked with different concentrations of AFB1. The developed competitive immunoelectrode displays good reproducibility, and storage stability and regenerated with negligible loss in activity through removal of the $\mathrm{r}-\mathrm{IgG}-\mathrm{Cys}-\mathrm{Au}-\mathrm{Fe}_{3} \mathrm{O}_{4}$ conjugate using a strong external magnet.
\end{abstract}

\section{Introduction}

Aflatoxin B1 (AFB1), which is a low molecular mass compound mainly produced by the moulds Aspergillus flavus and Aspergillus parasiticus, can contaminate several important crops (e.g., corn, sorghum, peanuts, fruits, dried fruits, cocoa, and spices) under favorable environmental conditions [1, 2]. Owing to high toxicity and carcinogenicity, AFB1 is of major concern for food producers, the food processing industry, and consumers [3]. The European Commission has set the maximum permissible residue levels for AFB1 in corn products ready for retail sale at $2 \mu \mathrm{g} \mathrm{kg}^{-1}$ [4-7]. Compared to conventional techniques [8-10], immunosensors are an interesting alternative that can be used to quantify and detect selectively toxin molecules [11-14]. Some of the biosensing techniques used for AFB1 detection include electrochemical biosensors [15, 16], surface plasmon resonance [17, 18], fluorescent biosensors $[19,20]$, and quartz crystal (piezoelectric) microbalance based sensors [21, 22]. Among the signal detection techniques, quartz crystal microbalance (QCM) based detection systems are considered to be the most promising for immunointeraction owing to their affordable cost and real-time and label-free compatibility with miniaturization, portability, and high sensitivity [23-25].

The immunosensors which employ monoclonal antibody, synthesized from animal source as a receptor, are fast and efficient technique no doubt but are expensive and used for one time only. Therefore it will be advantageous to develop reusable immunosensor which can be regenerated mechanically without any chemical as the chemicals affect biological activity of the receptor antibody [26, 27]. In 2009, Wang and Gan have used magnetic core-shell $\mathrm{Fe}_{3} \mathrm{O}_{4} / \mathrm{SiO}_{2}$ composite nanoparticles to regenerate the QCM crystal. In this regard, magnetic nanoparticles (MNP) can be considered as one of the potential tools to regenerate immunosensor using strong external magnet [28]. The MNP is commonly used in the coated form to gain biocompatibility and stability $[29,30]$. Since AFB1 is a low molecular weight (Mwt. 312) molecule, competitive mode of detection could provide the desired detection limit and sensitivity $[31,32]$. The competition occurs between coated toxin (toxin-protein conjugate) 
and free toxin. The few binding sides of coated toxin (antigenprotein complex) are partially blocked through the toxinprotein binding. Therefore, the secondary antibody captures free toxin leaving heavy toxin-protein complex.

In this study, a sandwich type electrochemical quartz crystal microbalance (EQCM) based reusable immunosensor (BSA/aAFB1/4-ATP/Au) was fabricated using self-assembled monolayer of 4-aminothiophenol on gold coated quartz crystal. The gold coated magneto nanoparticles attached to the secondary antibody were used as a signal enhancing agent and for regeneration of the immunoelectrode through external magnet. Both competitive and noncompetitive strategy are studied. Here, competition occurs between free AFB1 and coated AFB1 (with no protein bonded). Interestingly, we have observed that competition mode offers wider linearity, lower detection range, and higher sensitivity. The constructed immunosensor can be used for estimation of aflatoxin B1 from sample and regenerated with negligible loss of activity using a strong external magnet.

\section{Experimental Methods}

2.1. Chemicals and Reagents. Monoclonal anti-aflatoxin B1 (aAFB1) antibodies, aflatoxin B1 (AFB1), bovine serum albumin (BSA), polyclonal IgG antibodies from rabbit ( $r-\operatorname{IgG})$, 4-aminothiophenol (4-ATP), $N$-ethyl- $N$-(3-dimethylaminopropyl) carbodiimide (EDC), $N$-hydroxysuccinimide (NHS), ferrous chloride hexahydrate $\left(\mathrm{FeCl}_{2} \cdot 6 \mathrm{H}_{2} \mathrm{O}\right)$, ferric chloride tetrahydrate $\left(\mathrm{FeCl}_{3} \cdot 4 \mathrm{H}_{2} \mathrm{O}\right)$, sodium hydroxide $(\mathrm{NaOH})$, and chloroauric acid $\left(\mathrm{HAuCl}_{4} \cdot \mathrm{H}_{2} \mathrm{O}\right)$ were procured from SigmaAldrich. All reagents were of analytical grade and used without further purification, and deionized water $(18 \mathrm{M} \Omega$ $\mathrm{cm}$ ) was used for the preparation of solutions. The gold coated (diameter: $6.7 \mathrm{~mm}$ ) quartz resonator (AT cut quartz crystal, $13.7 \mathrm{~mm}$ dia, $6 \mathrm{MHz}$ ) was procured from Autolab, Netherlands.

2.2. Solution Preparation. Anti-AFB1 antibody $\left(1 \mathrm{mg} \mathrm{mL}^{-1}\right)$ solution was prepared in $50 \mathrm{mM}$ phosphate buffer (PBS), $50 \mathrm{mM}, \mathrm{pH} 7.4$, and a $0.15 \mathrm{M} \mathrm{NaN}_{3}$ was used as a preservative. r-IgG antibody $\left(2 \mathrm{mg} \mathrm{mL}^{-1}\right)$ solution was prepared in $50 \mathrm{mM}$ PBS ( $\mathrm{pH} 7.4$ ). The stock solution of AFB1 was prepared in PBS (50 mM, pH 7.4) with $10 \%$ methanol and diluted in different working concentrations and stored at $-20^{\circ} \mathrm{C}$. A solution of bovine serum albumin (BSA, $1 \mathrm{mg} \mathrm{mL}^{-1}$ ) was prepared in $\mathrm{PBS}$ (50 mM, pH 7.0) and used as blocking agent for nonspecific binding sites.

2.3. Pretreatment of Quartz Crystals. The quartz crystals were immersed in $1 \mathrm{M} \mathrm{NaOH}$ for $5 \mathrm{~min}$ and $1 \mathrm{M} \mathrm{HCl}$ for $2 \mathrm{~min}$ in a sequence. Then, freshly prepared piranha solution $\{1: 3$ $\left.(30 \% \mathrm{v} / \mathrm{v}) \mathrm{H}_{2} \mathrm{O}_{2}-\mathrm{H}_{2} \mathrm{SO}_{4}\right\}$ was dropped on the gold surface for $2 \mathrm{~min}$, with special care to avoid the contamination of the electrode leads. The quartz crystals were rinsed twice with deionized water followed by ethanol and dried in a stream of nitrogen after each pretreatment and then the initial resonance frequency $\left(F_{0}\right)$ was recorded. After the above cleaning procedure, the quartz crystal was ready for surface modification and antibody immobilization.

2.4. Synthesis of $\mathrm{Fe}_{3} \mathrm{O}_{4}$ and $\mathrm{Au}$ Coated $\mathrm{Fe}_{3} \mathrm{O}_{4} \cdot \mathrm{Fe}_{3} \mathrm{O}_{4}$ NPs were synthesized simply by the coprecipitation method reported earlier [33] with some modification. Solution of $0.07 \mathrm{M}$ $\mathrm{FeCl}_{3} \cdot 6 \mathrm{H}_{2} \mathrm{O}$ and $0.04 \mathrm{M} \mathrm{FeCl}_{2} \cdot 4 \mathrm{H}_{2} \mathrm{O}(2: 1$, w/w ratio) was dissolved in $25 \mathrm{~mL}$ deionized water and then this mixture was added dropwise to the $100 \mathrm{~mL}$ solution of $0.15 \mathrm{mM} \mathrm{NaOH}$ with stirring under $\mathrm{N}_{2}$ atmosphere at room temperature. A black precipitate of $\mathrm{Fe}_{3} \mathrm{O}_{4}$ NPs was obtained. The black precipitate of $\mathrm{Fe}_{3} \mathrm{O}_{4}$ NPs thus obtained was dissolved in $20 \mathrm{~mL}$ citrate buffer ( $1.6 \mathrm{gm}$ citric acid and $0.8 \mathrm{gm}$ trisodium citrate) to stabilize ferrofluid in solution at a $\mathrm{pH}$ around 6.3.

The $\mathrm{Au}-\mathrm{Fe}_{3} \mathrm{O}_{4}$ core-shell NPs were prepared using $3 \mathrm{~mL}$ of the synthesized colloidal $\mathrm{Fe}_{3} \mathrm{O}_{4}$ nanosuspension $(0.1 \mathrm{M})$, boiled with $25 \mathrm{~mL}$ of ultrapure water under vigorous stirring condition. Then $0.2 \mathrm{mM} \mathrm{HAuCl}_{4}$ was added, followed by the addition of $10 \mathrm{mM}$ trisodium citrate, and the reaction mixture was kept boiling and stirring for $15 \mathrm{~min}$ till the color of the solution turned red from black. The gold coated $\mathrm{Fe}_{3} \mathrm{O}_{4} \mathrm{NPs}$ (Au- $\mathrm{Fe}_{3} \mathrm{O}_{4} \mathrm{NPs}$ ) solution was allowed to cool and stored in a dark glass bottle at $4^{\circ} \mathrm{C}$ before use.

2.5. Synthesis of $r-I g G-C y s-A u-\mathrm{Fe}_{3} \mathrm{O}_{4}$. Synthesized $\mathrm{Au}-\mathrm{Fe}_{3} \mathrm{O}_{4}$ nanosuspension was treated with $10^{-3} \mathrm{M}$ cysteamine and $\mathrm{HCl}$ in $1: 15$ volume ratio for $12 \mathrm{~h}$ at $25^{\circ} \mathrm{C}$. Cysteamine functionalized $\mathrm{Au}-\mathrm{Fe}_{3} \mathrm{O}_{4}$ NPs (Cys-Au- $\mathrm{Fe}_{3} \mathrm{O}_{4}$ ) were separated and purified by centrifugation at $10,000 \mathrm{rpm}$ for $10 \mathrm{~min}$. The purification and centrifugation process were repeated 4-5 times for removing nonbonded cysteamine. Then cysteamine functionalized $\mathrm{Au}-\mathrm{Fe}_{3} \mathrm{O}_{4}$ core-shell NPs were redispersed in $\mathrm{PB}(50 \mathrm{mM}, \mathrm{pH} 7.0)$ solution. Cysteamine forms a selfassembled layer on $\mathrm{Au}-\mathrm{Fe}_{3} \mathrm{O}_{4} \mathrm{NPs}$ which provides $\mathrm{NH}_{2}$ group to bind favorably with $\mathrm{COOH}$ functional group of the polyclonal r-IgG antibodies during immobilization. The r-IgG antibodies are mixed with Cys- $\mathrm{Au}-\mathrm{Fe}_{3} \mathrm{O}_{4}$ solution in $1: 3(\mathrm{v} / \mathrm{v}$ ratio) [34], followed by addition of $0.2 \mathrm{M}$ EDC and $0.05 \mathrm{M}$ NHS for the activation of - $\mathrm{COOH}$ group present in antibody. Further to block the nonspecific sites on the r-IgG-Cys-Au$\mathrm{Fe}_{3} \mathrm{O}_{4}$ conjugates, $100 \mu \mathrm{L}$ BSA $\left(1 \mathrm{mg} \mathrm{mL}^{-1}\right)$ was added and incubated for $2 \mathrm{~h}$ at $25^{\circ} \mathrm{C}$. The mixture was centrifuged at $10,000 \mathrm{rpm}$ for $10 \mathrm{~min}$ and washed for 4-5 times. Finally, the $\mathrm{r}$-IgG-Cys-Au- $\mathrm{Fe}_{3} \mathrm{O}_{4}$ conjugate was resuspended in $\mathrm{PB}$ (50 mM, pH 7.4) and stored at $4^{\circ} \mathrm{C}$ until use.

2.6. Fabrication of $A F B 1 / B S A / a A F B 1 / 4-A T P / A u$ Immunosensor. Pretreated quartz crystal was immersed in $2 \mathrm{mM}$ solution of 4-ATP in ethanol for $24 \mathrm{~h}$ at $25^{\circ} \mathrm{C}$ for SAM formation. However, a uniform and steady 4-ATP film was obtained [35]. The crystal was subsequently washed with ethanol followed by rinsing with water to remove any unbound ATP molecules. $10 \mu \mathrm{L}$ of the monoclonal anti-aflatoxin B1 (aAFB1) antibody, activated with $0.2 \mathrm{M} \mathrm{EDC}$ and $0.05 \mathrm{M}$ NHS for about $2 \mathrm{~h}$, was spread over the electrode and incubated overnight at $4^{\circ} \mathrm{C}$ for the amide bond formation between aAFB1 and 4-ATP. In this study, optimized concentration of $40 \mu \mathrm{g} \mathrm{mL}^{-1}$ of aAFB1 
was used. The nonspecific sites of fabricated immunoelectrodes were blocked with BSA $\left(1 \mathrm{mg} \mathrm{mL}^{-1}\right)$. These fabricated $\mathrm{BSA} / \mathrm{aAFB} 1 / 4-\mathrm{ATP} / \mathrm{Au}$ immunoelectrodes were exposed to saturated concentration of AFB1 $\left(5 \mathrm{ng} \mathrm{mL}^{-1}\right)$ for $35 \mathrm{~min}$ at $25^{\circ} \mathrm{C}$.

2.7. Pretreatment and Analysis of Cereal Samples. The cereal samples (corn flakes) were spiked after the treatment. Corn flakes samples were crushed to powder using a hand-held blender. $2 \mathrm{~g}$ of powdered cereals was added to methanol: water $(7: 3, \mathrm{v} / \mathrm{v})$ solution on a sonication bath for $45 \mathrm{~min}$. The extract was centrifuged for $7 \mathrm{~min}$ at $5000 \mathrm{rpm}$ to remove the solids. The supernatants were collected and allowed to evaporate to dryness under nitrogen at $25^{\circ} \mathrm{C}$. The residues were resuspended in $5 \mathrm{~mL}$ PBS and filtered through $0.45 \mu \mathrm{m}$ nylon membranes [36]. Finally, extract was spiked with the different concentrations of $0.05,2$, and $5 \mathrm{ng} \mathrm{mL}^{-1}$ of aAFB1.

2.8. Instrumentation. The resonant frequency of quartz crystal and electrochemical studies were monitored by Autolab Potentiostat/Galvanostat Model AUT83945 (PGSTAT302N). The electrochemical quartz crystal cyclic voltammetric (EQCM-CV) studies were carried out in a three-electrode cell using modified quartz crystal as the working electrode, gold wire as the auxiliary electrode, and saturated $\mathrm{Ag} / \mathrm{AgCl}$ as the reference electrode in PBS $(50 \mathrm{mM}$, $\mathrm{pH} 7.4,0.9 \% \mathrm{NaCl})$ containing $5 \mathrm{mM}\left[\mathrm{Fe}(\mathrm{CN})_{6}\right]^{3-/ 4-}$ as a redox species. The $\mathrm{Au}-\mathrm{Fe}_{3} \mathrm{O}_{4}$ core-shell magnetic nanoparticles were characterized by scanning electron microscopy (ZEISS EVO-18), vibrating sample magnetometer (VSM) (Microsense, ADE-Model EV9), transmission electron microscopy (JEOL JEM (Model 1200F)), and X-ray diffractometer from Bruker AXS (XRD). The structural and surface morphological characterizations of 4-ATP/Au, aAFB1/4-ATP/Au, BSA/aAFB1/4-ATP/Au, and $\mathrm{AFB} 1 / \mathrm{BSA} / a \mathrm{AFB} 1 / 4-\mathrm{ATP} / \mathrm{Au}$ electrode were carried out using Fourier transform infrared spectroscopy (FT-IR, Perkin-Elmer, Model 2000), scanning electron microscopy (ZEISS EVO-18), and Autolab Potentiostat/Galvanostat Model AUT83945 (PGSTAT302N).

\section{Results and Discussion}

3.1. Characterization of $\mathrm{Fe}_{3} \mathrm{O}_{4}$ and $\mathrm{Au}-\mathrm{Fe}_{3} \mathrm{O}_{4}$ Core-Shell Structure. Figure 1(a) shows the UV-Visible absorption spectrum of pure magnetic $\mathrm{Fe}_{3} \mathrm{O}_{4} \mathrm{NPs}, \mathrm{Au} \mathrm{NPs}$, and $\mathrm{Au}-\mathrm{Fe}_{3} \mathrm{O}_{4}$ (curve (c)) core-shell NPs. Typical absorption spectra of pure $\mathrm{Fe}_{3} \mathrm{O}_{4}$ NPs (curve (a)) exhibit absorption edge at $\sim 340 \mathrm{~nm}$. The absorption peak seen at $324 \mathrm{~nm}$ and the sharp absorption maxima at $527 \mathrm{~nm}$ (curve (b)) are assigned for pure Au NPs exhibiting strong absorption that is dependent on the size and shape of particles. For spherical nanoparticles, the absorption band maximum generally falls between about 520 and $532 \mathrm{~nm}$ [37]. The UV-Visible absorption spectrum of $\mathrm{Au}-\mathrm{Fe}_{3} \mathrm{O}_{4}$ coreshell (curve (c)) structure shows a broad peak at $532 \mathrm{~nm}$. The shifting of peak position towards longer wavelengths (red shift) and disappearance of peak edge arise due to $\mathrm{Fe}_{3} \mathrm{O}_{4}$, indicating the formation of bimetallic core-shell structure with the existence of $\mathrm{Fe}_{3} \mathrm{O}_{4}$ as core. Au covers the $\mathrm{Fe}_{3} \mathrm{O}_{4} \mathrm{NPs}$ surface and provides a broad shifted peak at $532 \mathrm{~nm}$ due to inherent surface plasmon resonance property of Au NPs.

The magnetic properties of $\mathrm{Fe}_{3} \mathrm{O}_{4} \mathrm{NPs}$ and $\mathrm{Au}-\mathrm{Fe}_{3} \mathrm{O}_{4}$ core-shell structure were analyzed by vibrating sample magnetometer (VSM) at $17 \mathrm{~K}$. Figure $1(\mathrm{~b})$ shows the hysteresis loop measured for the $\mathrm{Fe}_{3} \mathrm{O}_{4}$ NPs (curve (a)), $\mathrm{Fe}_{3} \mathrm{O}_{4}$ NPs in citrate buffer (curve (b)), and $\mathrm{Au}-\mathrm{Fe}_{3} \mathrm{O}_{4}$ core-shell structure (curve (c)). The values of saturated magnetization from the hysteresis curve of the pure $\mathrm{Fe}_{3} \mathrm{O}_{4} \mathrm{NPs}$ and $\mathrm{Fe}_{3} \mathrm{O}_{4}$ NPs in buffer were found to be 0.0028 and $0.0085 \mathrm{emu} / \mathrm{g}$, respectively, at $17 \mathrm{~K}$. The saturated magnetization of $\mathrm{Fe}_{3} \mathrm{O}_{4}$ NPs dispersed in citrate buffer was increased by $\sim 4$ times compared with the precipitated $\mathrm{Fe}_{3} \mathrm{O}_{4}$ NPs indicating uniform dispersion of $\mathrm{Fe}_{3} \mathrm{O}_{4}$ particles in citrate buffer. In the dispersed form, each NP acts like a tiny magnet, resulting in a higher magnetic moment density than that of precipitated $\mathrm{Fe}_{3} \mathrm{O}_{4} \mathrm{NPs}$. The saturated specific magnetization of $\mathrm{Au}-\mathrm{Fe}_{3} \mathrm{O}_{4}$ core-shell structure decreases to $0.0022 \mathrm{emu} / \mathrm{g}$. This decrease may be due to the fact that the gold is a nonmagnetic material, which could decrease the saturated specific magnetization [38] indicating that the gold was successfully coated on $\mathrm{Fe}_{3} \mathrm{O}_{4}$ $\mathrm{NPs}$ to form $\mathrm{Au}-\mathrm{Fe}_{3} \mathrm{O}_{4}$ core shell.

EQCM-CV (Figure 1(c)) of $\mathrm{Fe}_{3} \mathrm{O}_{4}$ NPs dispersion and $\mathrm{Au}-\mathrm{Fe}_{3} \mathrm{O}_{4}$ NPs were studied in PBS buffer $(50 \mathrm{mM}, \mathrm{pH} 7.4$, $0.9 \% \mathrm{NaCl})$ containing $5 \mathrm{mM}\left[\mathrm{Fe}(\mathrm{CN})_{6}\right]^{3-/ 4-} .100 \mu \mathrm{L}$ of NPs dispersion was added to buffer to conduct $\mathrm{CV}$ at a scan rate of $100 \mathrm{mV} / \mathrm{s}$ in the potential range of -0.2 to $0.8 \mathrm{~V}$ $\{$ Figure $1(\mathrm{c})(\mathrm{a}, \mathrm{b}$, and c) $\}$. Curve (a) represents the EQCM-CV of $\left[\mathrm{Fe}(\mathrm{CN})_{6}\right]^{3-/ 4-}$ redox system in PBS buffer. The magnitude of the peak current increases after adding $\mathrm{Fe}_{3} \mathrm{O}_{4}$ NPs (curve (b)) which further increases on adding $\mathrm{Au}-\mathrm{Fe}_{3} \mathrm{O}_{4}$ core shell (curve (c)) showing an enhanced electron transform rate through the medium to surface of electrode and confirming the $\mathrm{Au}$ is successfully coated onto $\mathrm{Fe}_{3} \mathrm{O}_{4}$ NPs.

To confirm the formation of $\mathrm{Au}-\mathrm{Fe}_{3} \mathrm{O}_{4} \mathrm{NPs}$, EDX analysis has been studied for elemental composition in $\mathrm{Fe}_{3} \mathrm{O}_{4}$ and $\mathrm{Au}$ $\mathrm{Fe}_{3} \mathrm{O}_{4}$ NPs. Figure 2(a) (images (A) and (B) for $\mathrm{Fe}_{3} \mathrm{O}_{4}$ and $\mathrm{Au}-\mathrm{Fe}_{3} \mathrm{O}_{4} \mathrm{NPs}$ ) shows the presence of Fe peak at $6.8 \mathrm{keV}$ and absence of Au peak in image (A), while image (B) shows peaks both for $\mathrm{Au}$ at $2.4 \mathrm{keV}$ and $9.5 \mathrm{keV}$ and for $\mathrm{Fe}$ at $0.58 \mathrm{keV}$, $6.5 \mathrm{keV}$, and $7.1 \mathrm{keV}$, respectively. The weight percentage of these elements, shown as insets of respective images, indicates the presence of corresponding elements.

Figure 2(b) shows the TEM images of $\mathrm{Fe}_{3} \mathrm{O}_{4} \mathrm{NPs}, \mathrm{Fe}_{3} \mathrm{O}_{4}$ NPs in citrate buffer, and $\mathrm{Au}-\mathrm{Fe}_{3} \mathrm{O}_{4} \mathrm{NPs}$. The average particle size of $\mathrm{Fe}_{3} \mathrm{O}_{4} \mathrm{NPs}, \mathrm{Fe}_{3} \mathrm{O}_{4}$ NPs in citrate buffer, and $\mathrm{Au}$ $\mathrm{Fe}_{3} \mathrm{O}_{4}$ NPs was $\sim 8 \mathrm{~nm}, \sim 13 \mathrm{~nm}$, and $\sim 19 \mathrm{~nm}$, respectively. Figure 2(b), image (A), shows $\mathrm{Fe}_{3} \mathrm{O}_{4}$ NPs overlap each other, while image (B) shows the uniform distribution of $\mathrm{Fe}_{3} \mathrm{O}_{4} \mathrm{NPs}$ in ionic citrate buffer. It reveals that in buffer solution ionic citrate layer surrounds the $\mathrm{Fe}_{3} \mathrm{O}_{4}$ NPs. Image (C) presents the $\mathrm{Au}-\mathrm{Fe}_{3} \mathrm{O}_{4}$ core-shell NPs having bilayer structure with a dark center surrounded by a lighter layer. The molecular $d$ spacing is $0.48 \mathrm{~nm}$ for darker part and $0.23 \mathrm{~nm}$ (from ImageJ software) for light part of shell. The lattice distances measured for the shell correspond to the known Au lattice parameters 


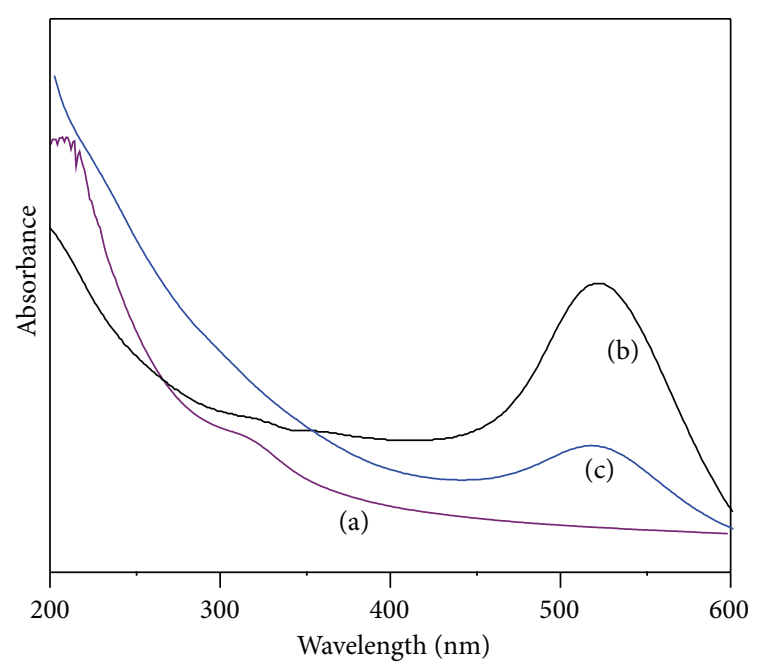

(a)

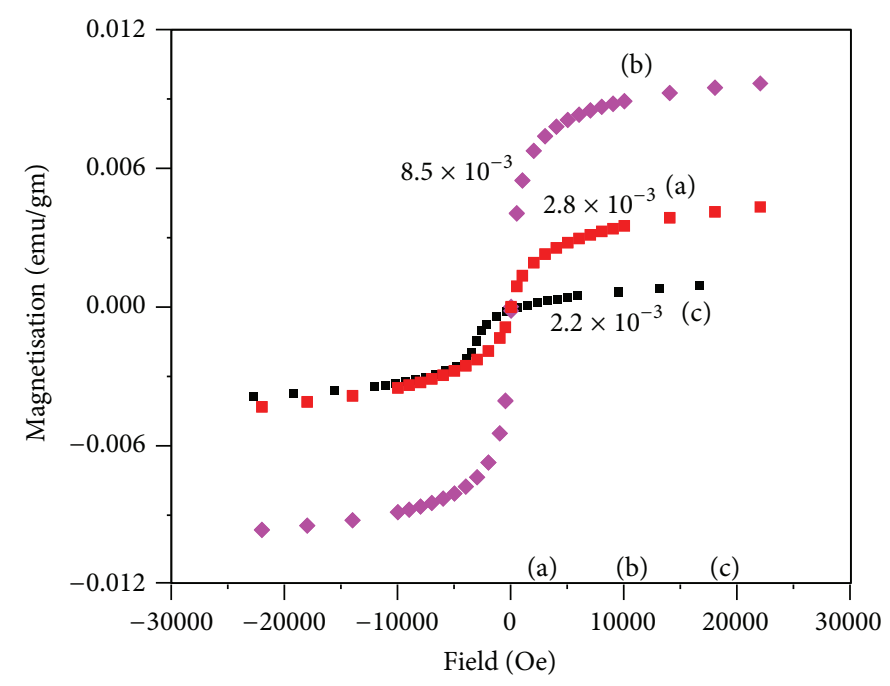

(b)

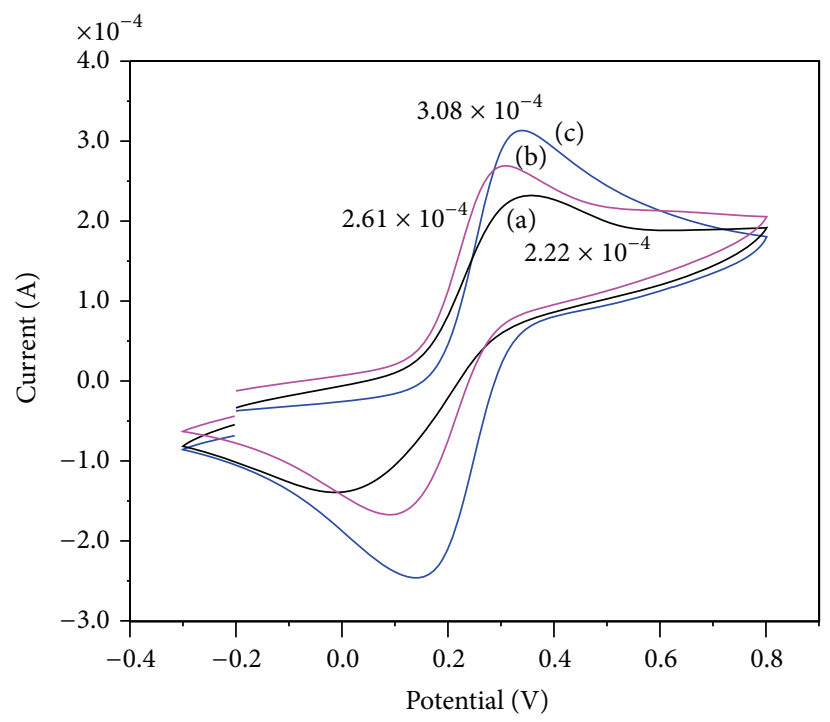

(c)

Figure 1: (a) UV-Visible spectra of (a) $\mathrm{Fe}_{3} \mathrm{O}_{4}$, (b) Au NPs, and (c) Au- $\mathrm{Fe}_{3} \mathrm{O}_{4}$ NPs. (b) VSM of (a) $\mathrm{Fe}_{3} \mathrm{O}_{4}$, (b) $\mathrm{Fe}_{3} \mathrm{O}_{4}$ in citrate buffer, and (c) $\mathrm{Au}-\mathrm{Fe}_{3} \mathrm{O}_{4}$ NPs. (c) CV of (a) bare Au crystal, (b) $\mathrm{Fe}_{3} \mathrm{O}_{4}$, and (c) Au- $\mathrm{Fe}_{3} \mathrm{O}_{4} \mathrm{NPs}$ in PBS containing $\left[\mathrm{Fe}(\mathrm{CN})_{6}\right]^{3-/ 4-}$.

for the (111) plane and those measured for the core match well the $\mathrm{Fe}_{3} \mathrm{O}_{4}$ lattice parameters for the (311) plane. The presence of these two phases is also confirmed by X-ray diffraction (XRD) analysis. The XRD pattern of the $\mathrm{Fe}_{3} \mathrm{O}_{4} \mathrm{NPs}$ and $\mathrm{Au}-$ $\mathrm{Fe}_{3} \mathrm{O}_{4}$ core-shell NPs, demonstrated in Figures 2(c) (a) and 2(c) (b), shows diffraction peaks at $2 \theta 30.15^{\circ}, 35.76^{\circ}, 43.2^{\circ}$, $53.6^{\circ}, 57.6^{\circ}$, and $62.96^{\circ}$ for $\mathrm{Fe}_{3} \mathrm{O}_{4}$ which exhibit indexed (220), (311), (400), (422), (511), and (440). For Au- $\mathrm{Fe}_{3} \mathrm{O}_{4}$ (graph (b)), the characteristic peaks seen at $38.28^{\circ}, 44.43^{\circ}, 59.1^{\circ}, 64.70^{\circ}$, and $77.81^{\circ}$, marked by their indices (111), (200), (220), (311), and (222), are observed indicating that the $\mathrm{Fe}_{3} \mathrm{O}_{4}$ in $\mathrm{Au}-$ $\mathrm{Fe}_{3} \mathrm{O}_{4}$ NPs resembles pure $\mathrm{Fe}_{3} \mathrm{O}_{4}$ with a spinal hexagonal structure $[39,40]$.

3.2. Characterization of $r-I g G-C y s-A u-\mathrm{Fe}_{3} \mathrm{O}_{4}$. The conjugate formation of r-IgG-Cys- $\mathrm{Au}-\mathrm{Fe}_{3} \mathrm{O}_{4}$ was confirmed by
UV-absorption spectroscopy (Figure 3(a)). The absorbance maxima for the pure r-IgG antibody solution appear at $250 \mathrm{~nm}$ (curve (a)) whereas the r-IgG-Cys-Au- $\mathrm{Fe}_{3} \mathrm{O}_{4}$ conjugate shows two peaks observed at $258 \mathrm{~nm}$ for r-IgG and $529 \mathrm{~nm}$ for $\mathrm{Au}-\mathrm{Fe}_{3} \mathrm{O}_{4}$ (curve (b)). Broadening in peaks and slight red shift are also observed in both peaks due to increased size of NPs. These results indicate that the $\mathrm{r}-\mathrm{IgG}$ antibodies are immobilized onto the surface of the Cys-Au$\mathrm{Fe}_{3} \mathrm{O}_{4}$ core-shell structure. Scheme 1 represents the formation of $\mathrm{r}-\mathrm{IgG}-\mathrm{Cys}-\mathrm{Au}-\mathrm{Fe}_{3} \mathrm{O}_{4}$ conjugate.

The EQCM-CV (Figure 3(b)) of cysteamine functionalized $\mathrm{Au}-\mathrm{Fe}_{3} \mathrm{O}_{4}$ NPs and $\mathrm{r}-\mathrm{IgG}-\mathrm{Au}-\mathrm{Fe}_{3} \mathrm{O}_{4}$ conjugate corroborates the fabrication of secondary antibody conjugate with $\mathrm{Au}-\mathrm{Fe}_{3} \mathrm{O}_{4}$ NPs. EQCM-CV was studied in PBS buffer (50 mM, pH 7.4, 0.9\% NaCl) containing $5 \mathrm{mM}\left[\mathrm{Fe}(\mathrm{CN})_{6}\right]^{3-/ 4-}$ at a scan rate of $100 \mathrm{mV} / \mathrm{s}$ in the potential range of -0.2 


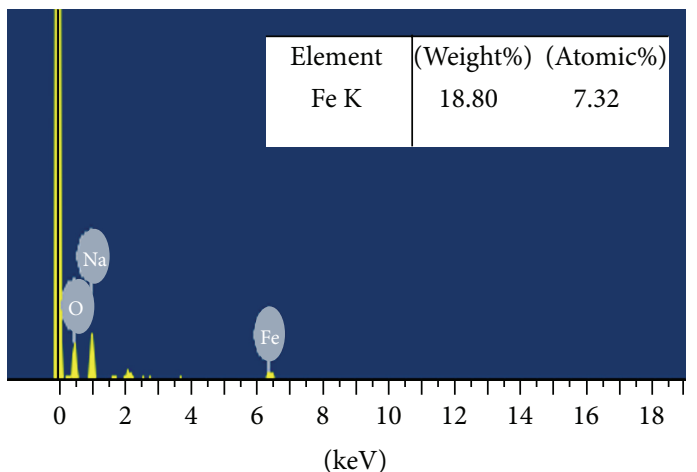

Full scale 1000 cts cursor: 0.000

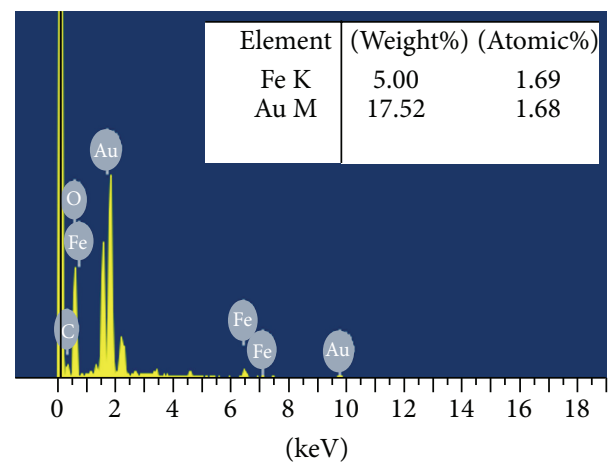

Full scale 1552 cts cursor: 0.000
(A)

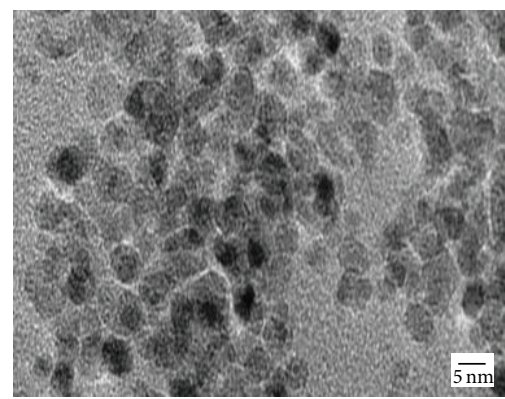

(A)

(B)

(a)

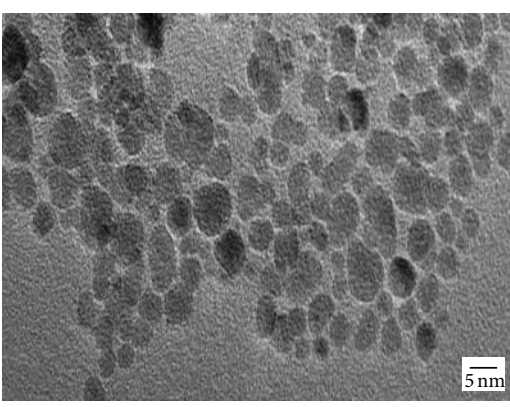

(B)

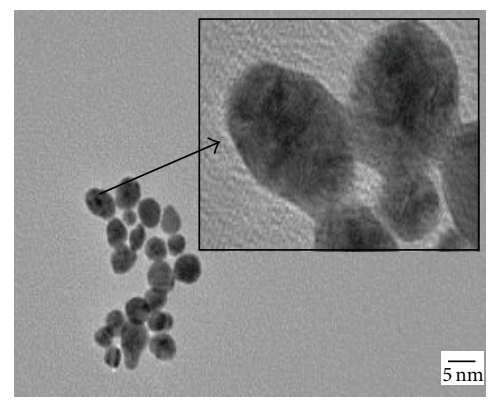

(C)

(b)

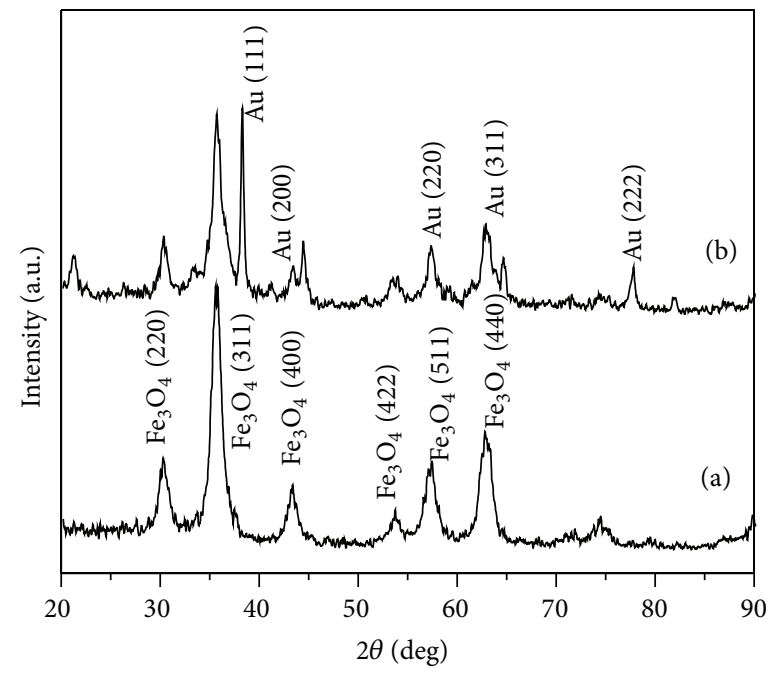

(c)

Figure 2: (a) EDX of (A) $\mathrm{Fe}_{3} \mathrm{O}_{4}$ NPs and (B) Au-Fe $\mathrm{O}_{4}$ NPs. (b) TEM image of (A) $\mathrm{Fe}_{3} \mathrm{O}_{4}$, (B) $\mathrm{Fe}_{3} \mathrm{O}_{4}$ in buffer, and (C) Au-Fe $\mathrm{O}_{4}$ NPs. (c) XRD of (a) $\mathrm{Fe}_{3} \mathrm{O}_{4}$ and (b) $\mathrm{Au}-\mathrm{Fe}_{3} \mathrm{O}_{4} \mathrm{NPs}$.

to $0.8 \mathrm{~V}$ \{Figure $3(\mathrm{~b})(\mathrm{a}, \mathrm{b}$, and $\mathrm{c})\} .100 \mu \mathrm{L}$ of conjugate dispersion was added to the buffer to conduct $\mathrm{CV}$ of conjugates. Curve (a) represents the EQCM-CV of Au$\mathrm{Fe}_{3} \mathrm{O}_{4}$ nanoparticles in $\left[\mathrm{Fe}(\mathrm{CN})_{6}\right]^{3-/ 4-}$ redox system in PBS buffer. The magnitude of the peak current decreases after functionalization of $\mathrm{Au}-\mathrm{Fe}_{3} \mathrm{O}_{4}$ nanoparticles with cysteamine (curve (b)); decrease in current occurs due to the insulating nature of cysteamine. The EQCM-CV of r-IgG-Au- $\mathrm{Fe}_{3} \mathrm{O}_{4}$ conjugate (curve $(\mathrm{c}))$ in $\left[\mathrm{Fe}(\mathrm{CN})_{6}\right]^{3-/ 4-}$ redox system results in increase in current, due to the presence of carboxyl and amine group throughout the IgG antibodies indicating the formation of $\mathrm{r}$-IgG-Cys-Au- $\mathrm{Fe}_{3} \mathrm{O}_{4}$ conjugates. 


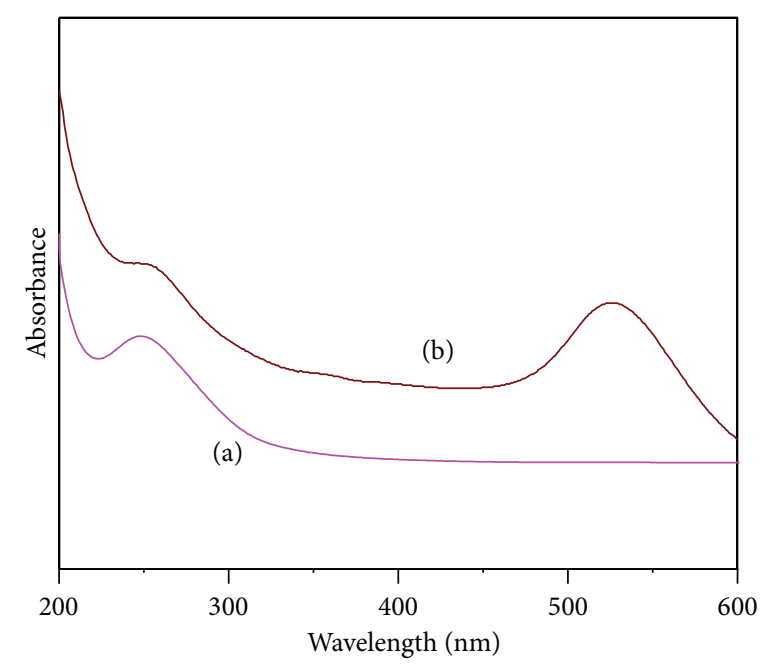

(a)

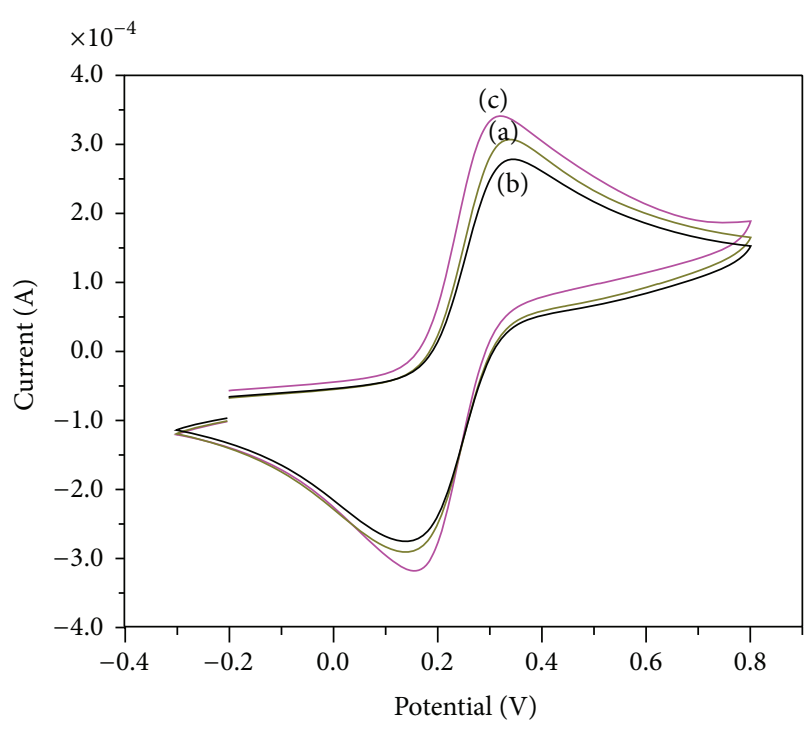

(b)

Figure 3: (a) UV-Visible spectra of (a) $\mathrm{r}$-IgG antibody and (b) $\mathrm{r}$-IgG-Cys-Au- $\mathrm{Fe}_{3} \mathrm{O}_{4}$ conjugate. (b) CV of (a) $\mathrm{Au}-\mathrm{Fe}_{3} \mathrm{O}_{4} \mathrm{NPs}$, (b) $\mathrm{Cys}-\mathrm{Au}-\mathrm{Fe} \mathrm{O}_{4}$ NPs, and (c) r-IgG-Cys-Au- $\mathrm{Fe}_{3} \mathrm{O}_{4}$ conjugate in PBS ( $\left.\mathrm{pH} 7.4\right)$ containing $\left[\mathrm{Fe}(\mathrm{CN})_{6}\right]^{3-/ 4-}$.
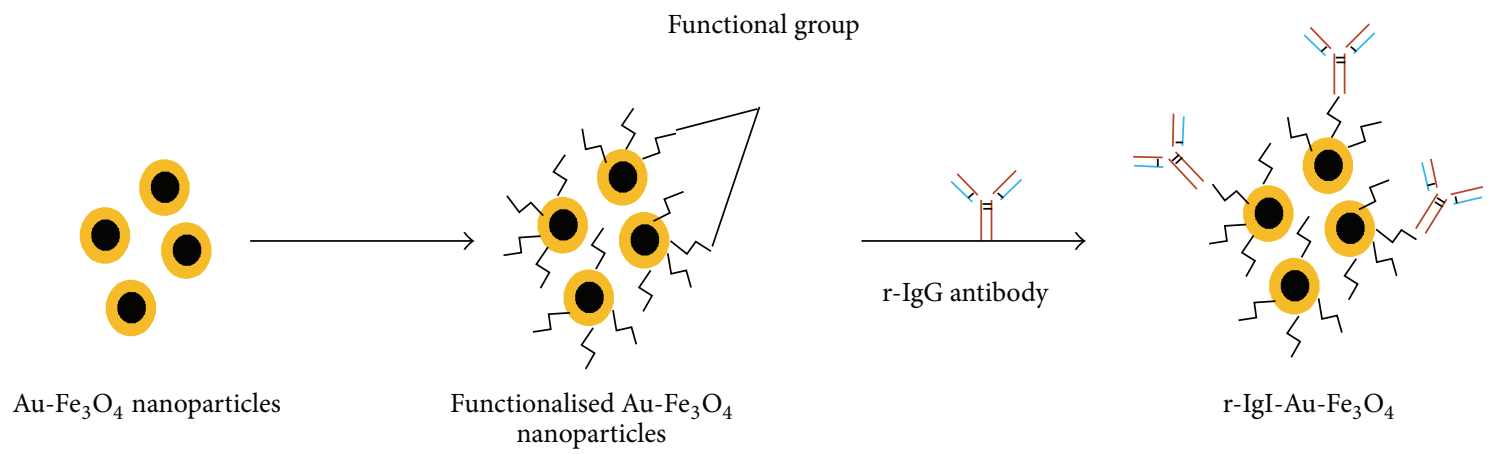

r-IgI-Au- $-\mathrm{Fe}_{3} \mathrm{O}_{4}$

Scheme 1: Scheme representing the formation of r-IgG-Cys-Au- $\mathrm{Fe}_{3} \mathrm{O}_{4}$ conjugate.

\subsection{Characterization of the Immunosensor}

3.3.1. Electrochemical Characterization of the Immunoelectrode. EQCM-CV shows both frequency and current changes. Figure 4(a) represents the change in frequency of QCM $(\Delta F)$ after the SAM deposition of 4-ATP on the bare gold crystal surface obtained at a scan rate of $100 \mathrm{mV} / \mathrm{s}$ in the potential range of -0.2 to $0.8 \mathrm{~V}$. The cleaned bare quartz crystal was taken as a reference. The frequency changes increase as mass increases on the electrode surface; the continuous increase in mass reveals the successive deposition of electrode.

Table 1 shows the list of mass deposition over the electrode at each layer. The successive deposition of various layers on $\mathrm{Au}$ quartz crystal is understood by mass change of $206.50 \mathrm{ng} \mathrm{cm}^{-2}$ for 4-ATP, $268.71 \mathrm{ng} \mathrm{cm}^{-2}$ for aAFB1 antibodies, and $396.196 \mathrm{ng} \mathrm{cm}^{-2}$ for BSA/aAFB1/4-ATP/Au electrode, respectively. After the competition the electrode surface mass increases drastically due to the formation of sandwiched between secondary antibody conjugate and monoclonal antibodies (r-IgG-Cys-Au-Fe ${ }_{3} \mathrm{O}_{4} / \mathrm{AFB} 1 / \mathrm{BSA} / \mathrm{aAFB1} / 4-\mathrm{ATP} / \mathrm{Au}$ )
TABLE 1: Change in frequency and mass during the fabrication of r-IgG-Cys-Au- $\mathrm{Fe}_{3} \mathrm{O}_{4} / \mathrm{AFB} 1 / \mathrm{BSA} / \mathrm{aAFB} 1 / 4-\mathrm{ATP} / \mathrm{Au}$ electrode.

\begin{tabular}{lccc}
\hline S. number & Electrode name & $\begin{array}{c}\text { Frequency } \\
\text { change } \\
(\mathrm{Hz})\end{array}$ & $\begin{array}{c}\text { Mass } \\
\text { change } \\
\left(\mathrm{ng} \mathrm{cm}^{-2}\right)\end{array}$ \\
\hline 1 & 4-ATP/Au & 16.83 & 206.50 \\
2 & aAFB1/4-ATP/Au & 21.19 & 268.71 \\
3 & $\mathrm{BSA} / \mathrm{aAFB} 1 / 4-\mathrm{ATP} / \mathrm{Au}$ & 32.29 & 396.19 \\
& $\mathrm{r}-\mathrm{IgG}-\mathrm{Cys}-\mathrm{Au}-$ & & \\
4 & $\mathrm{Fe}_{3} \mathrm{O}_{4} / \mathrm{AFB} 1 / \mathrm{BSA} / \mathrm{AAFB} 1 / 4-$ & 136.2 & 1668.71 \\
& ATP/Au & & \\
\hline
\end{tabular}

over the electrode (Table 1). These results are supported with EQCM-CV.

EQCM-CV (Figure 4(b)) was conducted in PBS (50 mM, $\mathrm{pH} 7.4,0.9 \% \mathrm{NaCl})$ containing $5 \mathrm{mM}\left[\mathrm{Fe}(\mathrm{CN})_{6}\right]^{3-/ 4-}$ as a redox species at a scan rate of $100 \mathrm{mV} / \mathrm{s}$ in the potential range of -0.2 to $0.8 \mathrm{~V}$. Figure 4 (b) shows $\mathrm{CV}$ of $\left[\mathrm{Fe}(\mathrm{CN})_{6}\right]^{3-/ 4-}$ of 


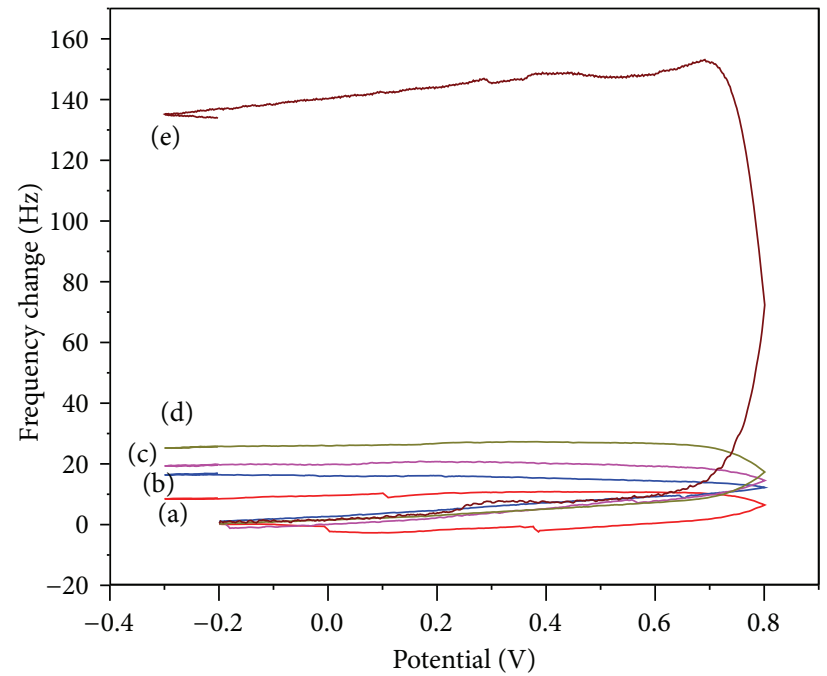

(a)

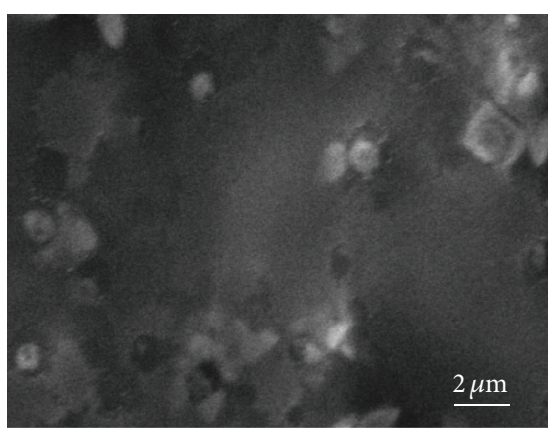

(A)

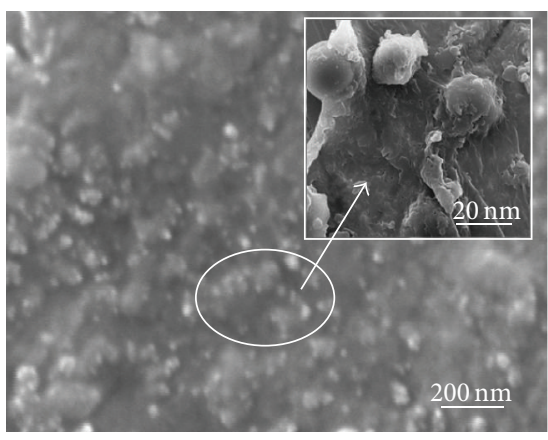

(C)

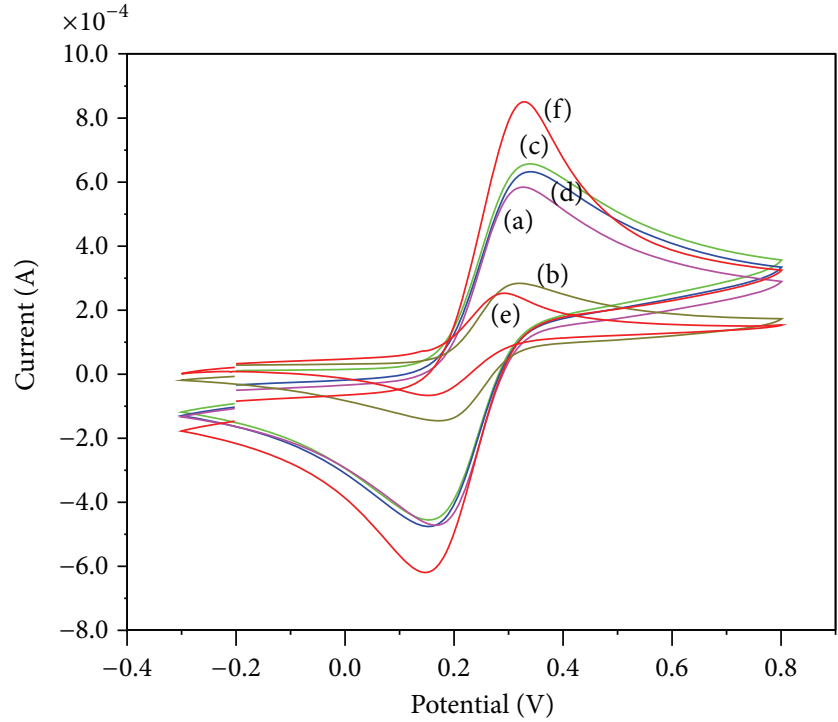

(b)

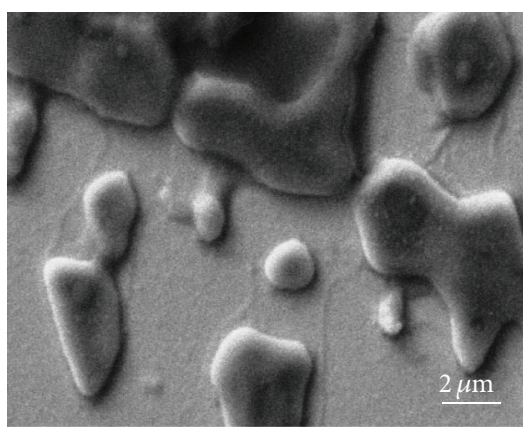

(B)

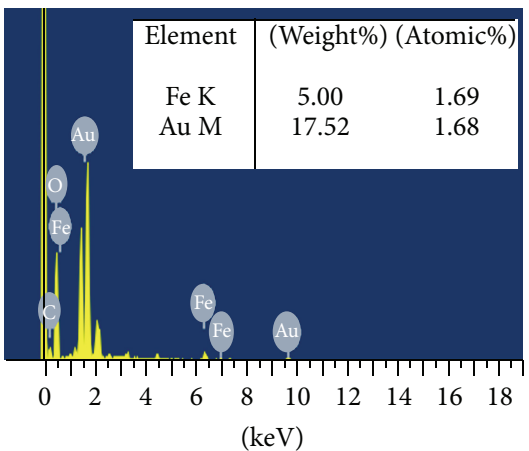

Full scale 1552 cts cursor: 0.000

(D)

(c)

Figure 4: ((a) and (b)) Frequency change and CV of (a) bare Au electrode, (b) 4-ATP/Au, (c) aAFB1/4-ATP/Au, (d) BSA/aAFB1/4$\mathrm{ATP} / \mathrm{Au}$, and (e) r-IgG-Cys-Au-Fe $\mathrm{O}_{4} / \mathrm{AFB} 1 / \mathrm{BSA} / \mathrm{aAFB} 1 / 4-\mathrm{ATP} / \mathrm{Au}$ immunoelectrodes. (c) SEM images of (A) aAFB1/4-ATP/Au, (B) $\mathrm{AFB} 1 / \mathrm{BSA} / \mathrm{aAFB} 1 / 4-\mathrm{ATP} / \mathrm{Au}$, and (C) r-IgG-Cys-Au-Fe $\mathrm{O}_{4} / \mathrm{AFB} 1 / \mathrm{BSA} / \mathrm{aAFB} 1 / 4-\mathrm{ATP} / \mathrm{Au}$ and (D) EDX of r-IgG-Cys-Au-Fe $3 \mathrm{O}_{4} / \mathrm{AFB} 1 /$ BSA/aAFB1/4-ATP/Au immunoelectrodes. 
a bare Au QCM electrode (curve (a)), 4-ATP/Au electrode (curve (b)), aAFB1/4-ATP/Au electrode (curve (c)), and BSA/aAFB1/4-ATP/Au electrode (curve (d)). After the SAM deposition, the magnitude of anodic peak current $(2.49 \times$ $10^{-4} \mathrm{~A}$ ) decreases (curve (b)), due to the insulating properties of the thin layer of thiol which hinders the electron movement through electrode of the gold surface. The presence of aAFB1 over the surface enhances the peak current up to $6.48 \times$ $10^{-4} \mathrm{~A}$ (curve (c)) due to the presence of polar groups of antibody such as carboxyl and amine moieties. There is a slight decrease in the magnitude of current response (6.17 $\times 10^{-4} \mathrm{~A}$ ) after immobilization of BSA onto the surface of AFB1/4-ATP/Au electrode, indicating enhanced electrontransfer barriers introduced upon assembly of BSA layer. After the competition, the magnitude of current increases $\left(8.31 \times 10^{-4}\right)$ due to the presence of $\mathrm{r}-\mathrm{IgG}-\mathrm{Cys}-\mathrm{Au}-\mathrm{Fe}_{3} \mathrm{O}_{4}$ conjugate over the surface of AFB1/BSA/aAFB1/4-ATP/Au immunoelectrode. It reveals that the IgG antibodies interact with AFB1 coated over the surface.

3.3.2. SEM Studies. The surface morphological studies of aAFB1/4-ATP/Au, AFB1/BSA/aAFB1/4-ATP/Au, and r-IgGCys-Au- $\mathrm{Fe}_{3} \mathrm{O}_{4} / \mathrm{AFB} 1 / \mathrm{BSA} / \mathrm{aAFB} 1 / 4-\mathrm{ATP} / \mathrm{Au}$ electrodes and immunoelectrodes were examined by scanning electron microscopy (SEM). Figure 4(c) represents the surface morphology of aAFB1/4-ATP/Au electrode (image (A)), showing highly dense globular morphology with bright streaks confirming the immobilization of aAFB1 onto 4-ATP/Au surface. Figure 4(c), image (B), shows the surface morphology of AFB1/BSA/aAFB1/4-ATP/Au electrode surface. The morphological changes in the SEM image after incubation of AFB1 indicate the binding of AFB1 to the aAFB1/4-ATP/Au electrode surface. Image $(C)$ shows the surface morphology of $r-$ IgG-Cys-Au- $\mathrm{Fe}_{3} \mathrm{O}_{4} / \mathrm{AFB} 1 / \mathrm{BSA} / \mathrm{aAFB} 1 / 4-\mathrm{ATP} / \mathrm{Au}$ immunoelectrode and the surface is saturated with r-IgG-Cys$\mathrm{Au}-\mathrm{Fe}_{3} \mathrm{O}_{4}$ conjugate. Inset image (image (C)) shows the morphology of $\mathrm{r}$-IgG-Cys-Au- $\mathrm{Fe}_{3} \mathrm{O}_{4} / \mathrm{AFB1} / \mathrm{BSA} / \mathrm{aAFB1} / 4-$ $\mathrm{ATP} / \mathrm{Au}$ at high magnification. It reveals that the secondary antibody interacts with coated antigen and forms sandwich like structure. Further, this fact is confirmed by EDX of this surface (Figure 4(c), image (D)) containing Fe and Au metal along with other elements and the weight\% shown in image (D) (inset table). The presence of these elements confirms the interaction of secondary antibody r-IgG-Cys$\mathrm{Au}-\mathrm{Fe}_{3} \mathrm{O}_{4}$ conjugate over the AFB1/BSA/aAFB1/4-ATP/Au immunoelectrode.

3.3.3. Atomic Force Microscopy (AFM). Topographic images were taken by AFM in noncontact mode $(1 \mu \mathrm{m} \times 1 \mu \mathrm{m}$ surface). In order to compare the topologies of each surface, surface roughness $\left(R_{a}\right)$ and root mean square roughness $\left(R_{q}\right)$ were estimated from the AFM images [41]. Figure 5 represents surface morphology of the bare Au (Figure 5(a)), 4-ATP/Au (Figure 5(b)), aAFB1/4-ATP/Au (Figure 5(c)), AFB1/BSA/aAFB1/4-ATP/Au (Figure 5(d)), and r-IgG-Cys$\mathrm{Au}-\mathrm{Fe}_{3} \mathrm{O}_{4} / \mathrm{AFB} 1 / \mathrm{BSA} / \mathrm{aAFB} 1 / 4-\mathrm{ATP} / \mathrm{Au}$ (Figure 5(e)) based immunosensors. The $R_{a}$ and $R_{q}$ values and surface topology for the bare gold surface and 4-ATP/Au electrode are similar.
Therefore, it can be assumed that a highly ordered and densely packed self-assembled layer of 4-ATP appears on the gold surface [42]. The drastic increase of surface roughness of aAFB1/4-ATP/Au (Figure 4(c)) as indicated by the values of $R_{a}(6.669 \mathrm{~nm}$ from $0.934 \mathrm{~nm})$ and $R_{q}(2.109 \mathrm{~nm}$ from $0.195 \mathrm{~nm}$ ) clearly demonstrates immobilization of the monoclonal aAFB1 antibody onto 4-ATP/Au electrode surface. The increase in $R_{a}$ and $R_{q}$ of aAFB1/4-ATP/Au immunosensor is attributed to the configuration and presence of paratope on antibody. After immobilization of BSA to block nonspecific sites, surface roughness further increases as observed by $R_{a}$ and $R_{q}$ values of $7.217 \mathrm{~nm}$ and $2.6 \mathrm{~nm}$, respectively (image not shown), which was also supported by SEM image. The $R_{a}$ and $R_{q}$ values have been found to be reduced to $1.895 \mathrm{~nm}$ and $0.563 \mathrm{~nm}$ of AFB1/BSA/aAFB1/4-ATP/Au (image 5(d)) after the interaction of antigen with the immobilized antibody. Therefore, sandwiched structure (image 5(e)) of $\mathrm{Au}$ NP functionalized secondary antibody, antigen, and monoclonal antibody (r-IgG-Cys-Au- $\mathrm{Fe}_{3} \mathrm{O}_{4} / \mathrm{AFB1} / \mathrm{BSA} / \mathrm{aAFB} 1 / 4-$ $\mathrm{ATP} / \mathrm{Au})$ is demonstrated by the rough surface topology and the $R_{a}(5.25 \mathrm{~nm})$ and $R_{q}(6.39 \mathrm{~nm})$ values.

3.3.4. FT-IR Studies. Figure 6 demonstrates FT-IR spectrum of the thiol monolayer between 500 and $3000 \mathrm{~cm}^{-1}$. The formation of a covalent gold-sulfur bond reveals the presence of the large band in the range of $624-640 \mathrm{~cm}^{-1}$ assigned to $\mathrm{C}-\mathrm{S}$ stretching mode (spectrum (a)). The observed bands at $804 \mathrm{~cm}^{-1}$ and $1461 \mathrm{~cm}^{-1}$ and broad band at $3340 \mathrm{~cm}^{-1}$ due to $=\mathrm{C}-\mathrm{H}$ deformation of the benzene ring, aromatic $-\mathrm{C}=\mathrm{C}-$ in-plane vibrations, and $\mathrm{N}-\mathrm{H}$ vibration of $\mathrm{NH}_{2}$ confirm the presence of 4-ATP on Au surfaces. After immobilization of aAFB1 on 4-ATP/Au electrode surface, the appearance of intense amide bands is characteristic of protein adsorption, amide I band at $1687 \mathrm{~cm}^{-1}$ corresponding to carbonyl $\mathrm{C}=\mathrm{O}$ stretching vibration and amide II band at $1594 \mathrm{~cm}^{-1}$ due to the coupled $\mathrm{C}-\mathrm{N}$ stretching, and $-\mathrm{N}-\mathrm{H}$ bending mode indicates successful immobilization of monoclonal antibodies [43] (Figure 6, spectrum (b)). Figure 6 (spectrum (c)) represents FT-IR spectrum of AFB1/BSA/aAFB1/4-ATP/Au, that is, after recognition of AFB1 by BSA/aAFB1/4-ATP/Au immunosensor. The presence of $1474 \mathrm{~cm}^{-1}$ for methyl adjacent to epoxy ring, $1308 \mathrm{~cm}^{-1}$ for in-plane $-\mathrm{CH}$ bending of phenyl in Figure 6 (spectrum (c)), clearly indicates the presence of AFB1 on the surface of aAFB1/4-ATP/Au surface [42]. The bands at $1098 \mathrm{~cm}^{-1}$ for symmetric stretching of $=\mathrm{C}-\mathrm{O}-\mathrm{C}$ or symmetric bending of phenyl and $938 \mathrm{~cm}^{-1}$ for possibly isolated $\mathrm{H}$ further confirm interaction between coated AFB1aAFB1 on the immunosensor surface. The band at $3414 \mathrm{~cm}^{-1}$ due to $-\mathrm{N}-\mathrm{H}$ stretching of $\mathrm{NH}_{2}$ group of the antibody almost disappears in the spectrum of AFB1/BSA/aAFB1/4-ATP/Au (Figure 6, (c)) indicating strong interaction between the antigen epitope and paratope of the antibody.

3.3.5. Response Studies of the Immunosensor. The sensitivity and detection limit of an immunosensor depend on antibody loading. Prior to sensing studies, we have optimized all the parameters like the concentration of aAFB1 $\left(40 \mu \mathrm{g} \mathrm{mL}^{-1}\right)$, 


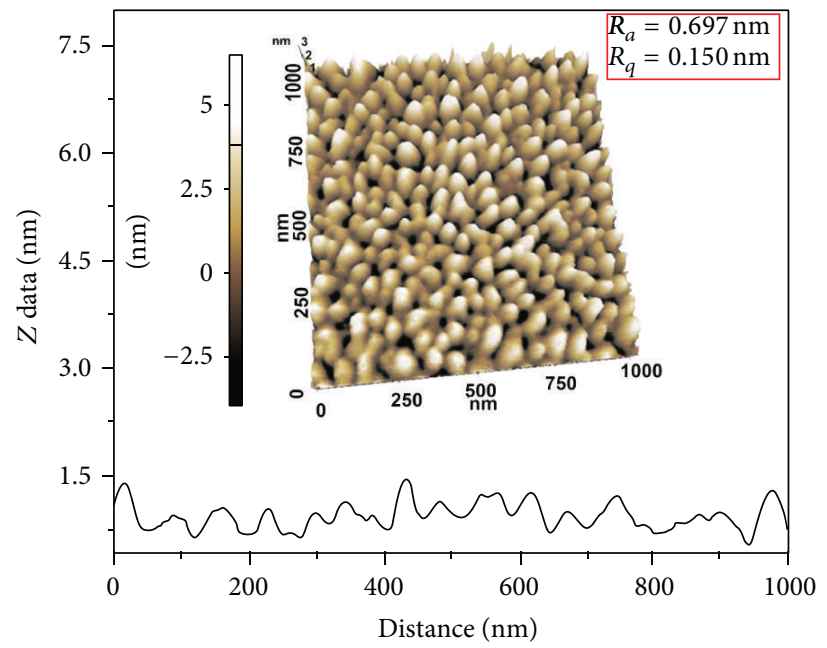

(a)

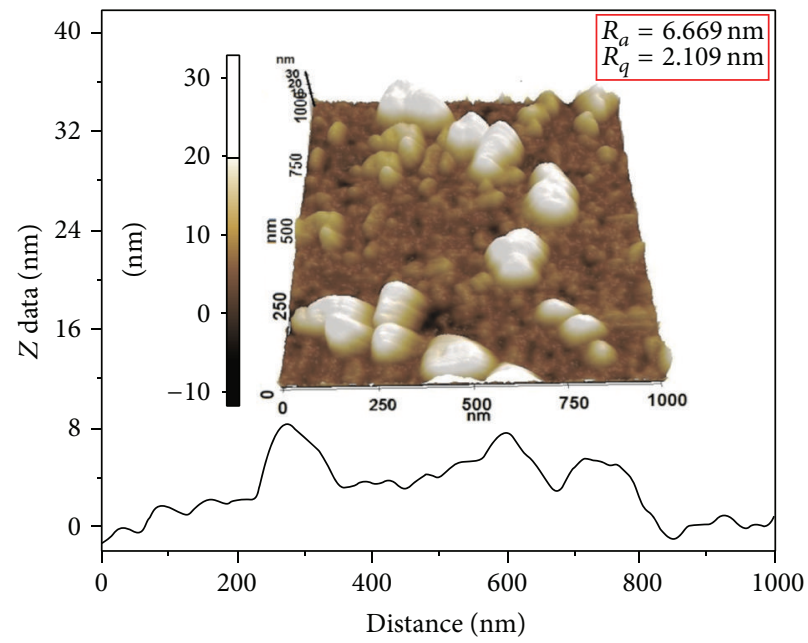

(c)

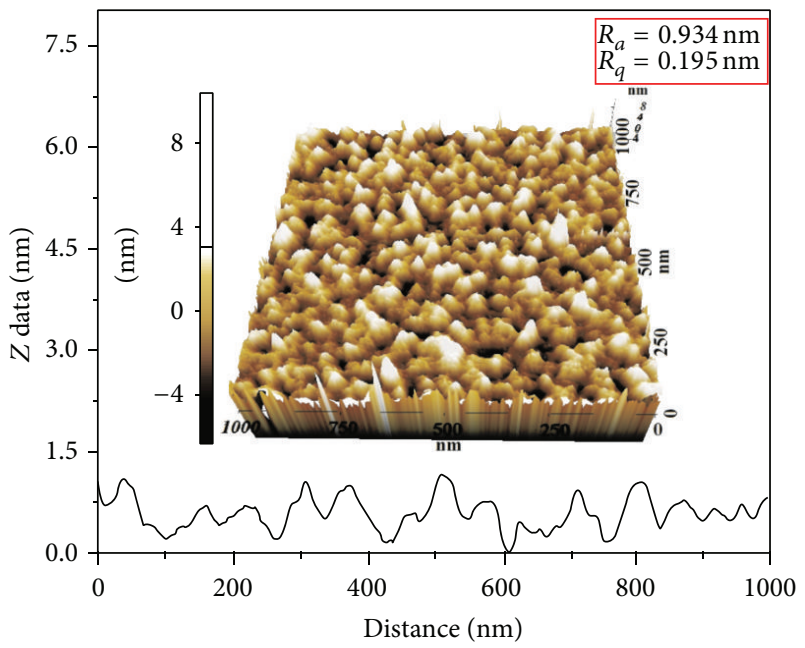

(b)

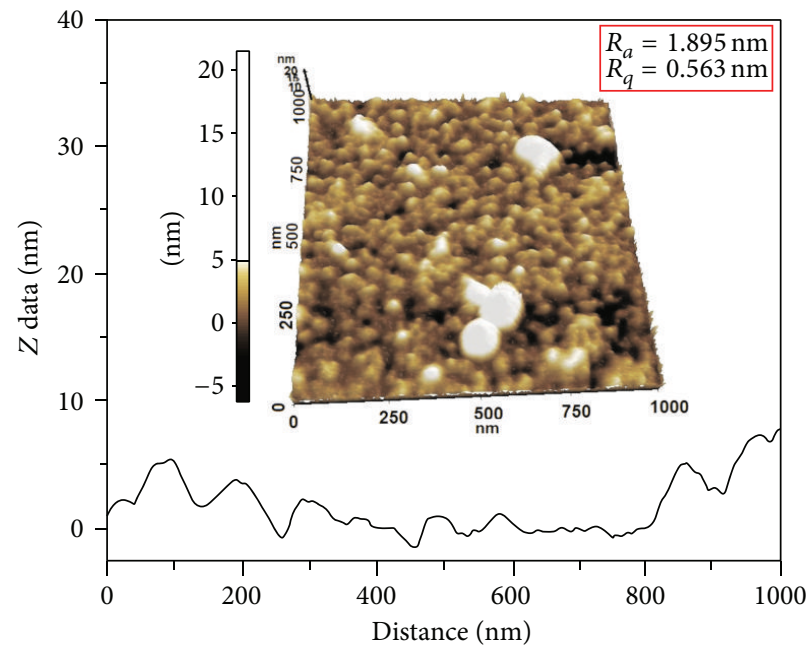

(d)

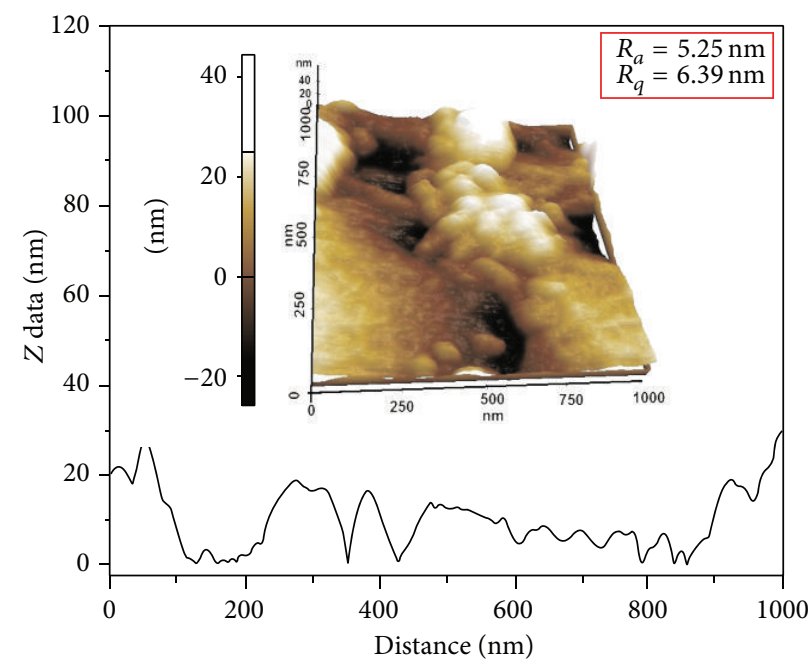

(e)

Figure 5: AFM images: topography image and height profiles of (a) bare Au, (b) 4-ATP/Au, (c) aAFB1/4-ATP/Au, (d) AFB1/BSA/aAFB1/4$\mathrm{ATP} / \mathrm{Au}$, and (e) r-IgG-Cys-Au- $\mathrm{Fe}_{3} \mathrm{O}_{4} / \mathrm{AFB1} / \mathrm{BSA} / \mathrm{aAFB1} / 4-\mathrm{ATP} / \mathrm{Au}$ immunosensor. 


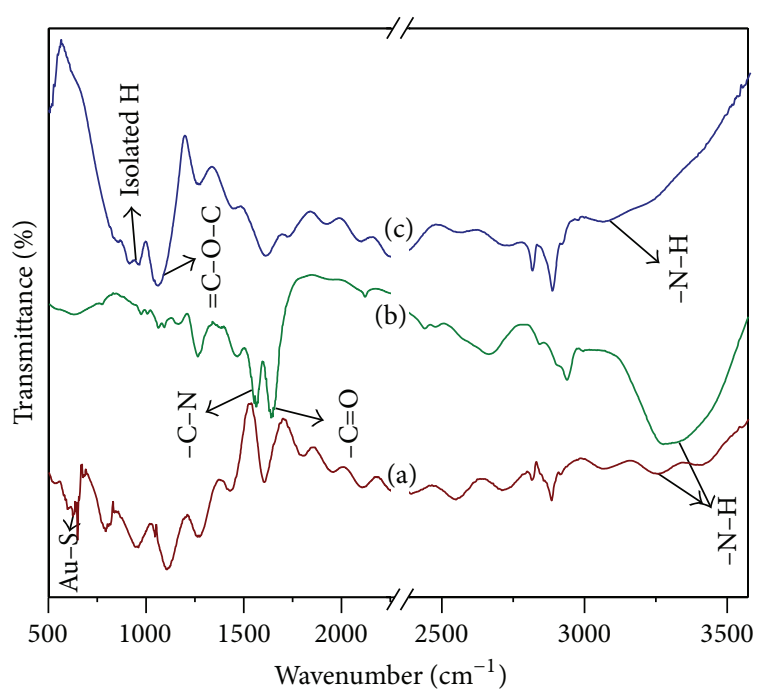

FIGURE 6: FT-IR of (a) 4-ATP/Au, (b) aAFB1/4-ATP/Au, and (c) AFB1/BSA/aAFB1/4-ATP/Au immunoelectrodes.

incubation time (30-35 min), and $\mathrm{pH}$ (7.4) in our previous study [35]. Further the concentration of r-IgG antibodies was optimized at $10-50 \mu \mathrm{g} \mathrm{mL}^{-1}$ (Figure $7(\mathrm{a})$ ). Figure $7(\mathrm{a})$ shows the current response of AFB1/BSA/aAFB1/4ATP/Au electrode with varying (different solution, $10-50 \mu \mathrm{g} \mathrm{mL} L^{-1}$ ) concentration of r-IgG-Cys-Au- $\mathrm{Fe}_{3} \mathrm{O}_{4}$ conjugate, current response increasing from 10 to $30 \mu \mathrm{g} \mathrm{mL}^{-1}$ after that decrease in current was observed, due to steric hindrance of conjugate or overloading of conjugates. Finally, $30 \mu \mathrm{g} \mathrm{mL}^{-1}$ concentration of $\mathrm{r}$-IgG-Cys-Au- $\mathrm{Fe}_{3} \mathrm{O}_{4}$ conjugate was applied over the AFB1/BSA/aAFB1/4ATP/Au electrode for all the experiments.

Both competitive and noncompetitive strategies have been investigated. In case of competitive mode, the BSA/ aAFB1/4-ATP/Au immunoelectrodes were fully covered with saturated concentration of AFB1 solution. Then the same (AFB1/BSA/aAFB1/4-ATP/Au) was allowed to interact with optimized concentration $\left(30 \mu \mathrm{gL}^{-1}\right)$ of secondary antibody conjugate ( $\mathrm{r}-\mathrm{IgG}-\mathrm{Cys}-\mathrm{Au}-\mathrm{Fe}_{3} \mathrm{O}_{4}$ ) and free AFB1 with varying concentration. Finally, the response in the sandwiched form was recorded with EQCM-CV after washing with $\mathrm{PB}$ in $\mathrm{N}_{2}$ atmosphere. During the competition process, secondary antibodies easily access free AFB1, while the rest of the $r-$ IgG-Cys-Au- $\mathrm{Fe}_{3} \mathrm{O}_{4}$ conjugates form sandwiched structure with the coated AFB1, respectively. Figure 7(b) shows calibration curve as a function of AFB1 concentration, linear range obtained from $0.05-5 \mathrm{ng} \mathrm{mL}^{-1}$ after which it decreases revealing that at $5 \mathrm{ng} \mathrm{mL}^{-1}$ concentration becomes saturated. The inset of Figure 7(b) shows the peak current intensity of the redox mediator is inversely proportional to the amount of free AFB1 in the sample and the peak current decreases with increase in concentration of AFB1. Scheme 2 represents the formation of this competitive sandwich type immunoelectrode. Each value is obtained in triplicate experiments and regression equation is obtained with a regression coefficient of ca. 0.98:

$$
\begin{aligned}
I(\mathrm{~A})= & \left(6.93 \times 10^{-4} \mathrm{~A}\right)-9.40 \times 10^{-5} \mathrm{~A} \mathrm{ng}^{-1} \mathrm{~mL} \\
& \times[\mathrm{AFB} 1] \mathrm{ng} \mathrm{mL}^{-1} .
\end{aligned}
$$

This corresponds to the sensitivity of ca. $335.7 \mu \mathrm{A} \mathrm{ng}^{-1} \mathrm{~mL} \mathrm{~cm}^{-2}$ for AFB1 with a calculated detection limit of $0.07 \mathrm{ng} \mathrm{mL}^{-1}$.

For noncompetitive mode, BSA/aAFB1/4-ATP/Au immunoelectrode was allowed to interact with increasing concentration of AFB1. After the interaction, the same (AFB1/BSA/aAFB1/4-ATP/Au) electrode was again exposed to optimum concentration of r-IgG-Cys- $\mathrm{Au}-\mathrm{Fe}_{3} \mathrm{O}_{4}$ conjugate to form sandwiched structure (r-IgG-Cys-Au$\mathrm{Fe}_{3} \mathrm{O}_{4} / \mathrm{AFB} 1 / \mathrm{BSA} / \mathrm{aAFB} 1 / 4-\mathrm{ATP} / \mathrm{Au}$ ). Figure 7(c) shows calibration curve as a function of AFB1 concentration, linear range obtained from $0.5-5 \mathrm{ng} \mathrm{mL}^{-1}$, after which it decreases revealing that at $5 \mathrm{ng} \mathrm{mL}^{-1}$ concentration it becomes saturated. In this case, the peak current increases (Figure 7(c) inset) with increasing concentration of AFB1 as the concentration of r-IgG-Cys-Au- $\mathrm{Fe}_{3} \mathrm{O}_{4}$ conjugate also increases enhancing the electron transfer through the medium by virtue of the presence of $\mathrm{Au}-\mathrm{Fe}_{3} \mathrm{O}_{4}$ nanoparticles on conjugate. All experiments were performed with triplicate measurements and the temperature was controlled at $25^{\circ} \mathrm{C}$. The calibration curve shows range of 0.5 to $5 \mathrm{ng} \mathrm{mL}^{-1}$ with calculated LOD of $0.9 \mathrm{ng} \mathrm{mL}^{-1}$ for the noncompetitive mode. However, the regression coefficient is 0.933 and the linear equation is as follows:

$$
\begin{aligned}
(\mathrm{A})= & \left(6.82 \times 10^{-4} \mathrm{~A}\right)+3.47 \times 10^{-5} \mathrm{~A} \mathrm{ng}^{-1} \mathrm{~mL} \\
& \times[\text { AFB1 }] \mathrm{ng} \mathrm{mL}^{-1} .
\end{aligned}
$$

This corresponds to the sensitivity of ca. $123.9 \mu \mathrm{A} \mathrm{ng}^{-1} \mathrm{~mL} \mathrm{~cm}^{-2}$. It reveals that the competitive mode offers a wider linear range, higher sensitivity, and lower LOD and corresponds to higher regression coefficient in spite of identical nature of coated AFB1 and free AFB1.

3.3.6. Real Sample Testing and Selectivity of Immunoelectrode. To evaluate the applicability of the developed immunosensor to real sample analysis, corn flakes samples were spiked with various concentrations of AFB1. For this the corn flakes sample extracted with a methanolic solution of potassium bicarbonate was exploited as a real sample. Evaporation to dryness and final reconstitution in PBS buffer were necessary to avoid the inhibition of the antibody-antigen binding caused by methanol. The extract sample was spiked with three different concentrations of $\mathrm{AFB} 1\left(0.05,2\right.$, and $\left.5 \mathrm{ng} \mathrm{mL}^{-1}\right)$ to examine the applicability of the proposed probe. During these experiments, the AFB1/BSA/aAFB1/4-ATP/Au immunosensor was dipped in the cell containing a mixture of different concentration of AFB1 spiked extracted sample and fixed amount of r-IgG-Cys/Au- $-\mathrm{Fe}_{3} \mathrm{O}_{4}$ in PBS and incubated for $35 \mathrm{~min}$. The EQCM-CV of AFB1/BSA/aAFB1/4-ATP/Au immunosensor was examined with the corn flakes extract 


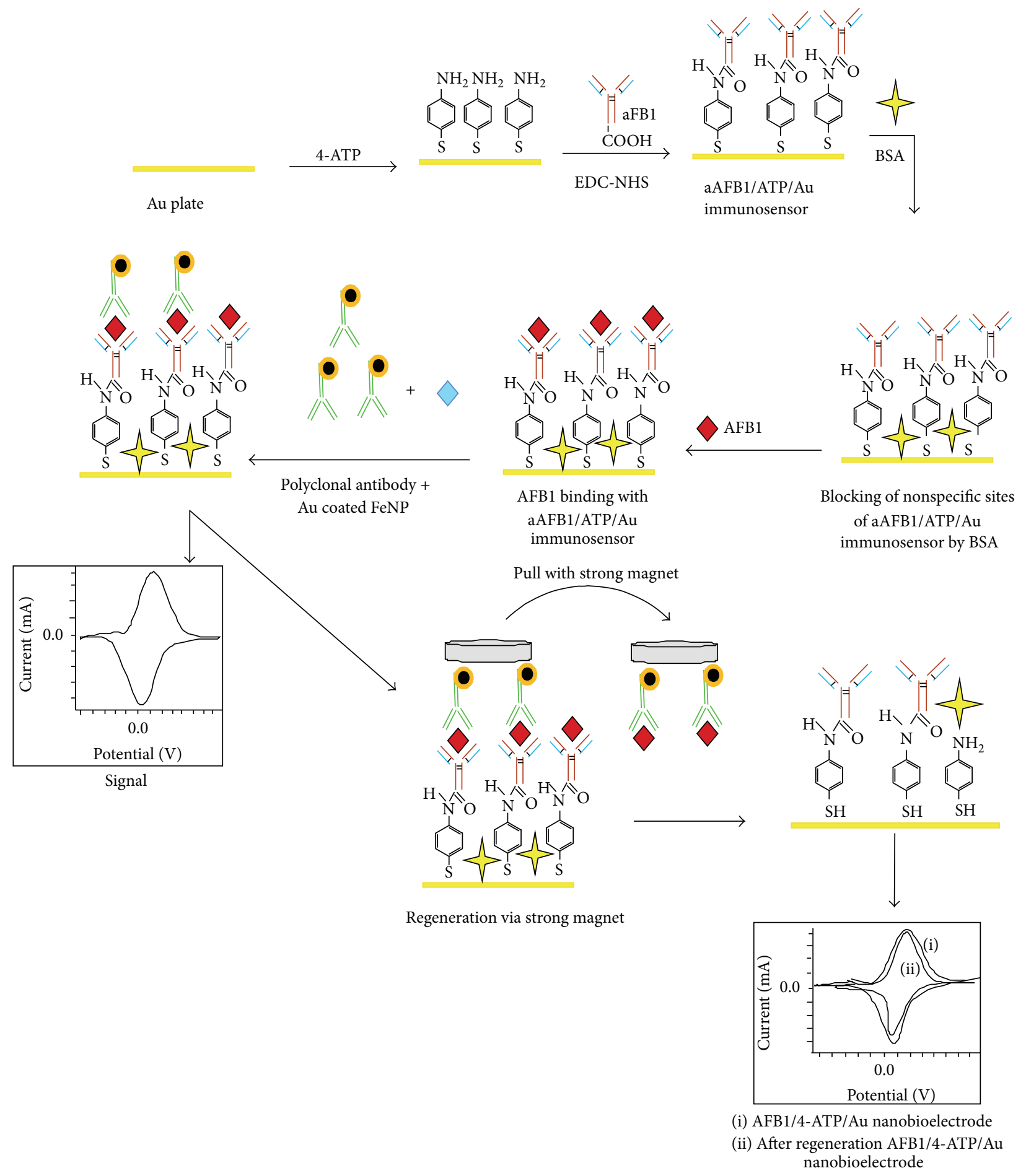

SCHEME 2: Scheme representing the formation of this competitive sandwich type immunoelectrode.

in PBS, which reflects the minimum interference. Variation of peak current in blank and corn flakes extract is [Figure 8(a) (bars (1) and (2))] within 5\%. It indicates that the AFB1/BSA/aAFB1/4-ATP/Au immunosensor shows the specificity towards the AFB1 antigen, not inflated with other constituents present in the corn flakes sample. However, the response of the AFB1/BSA/aAFB1/4-ATP/Au immunosensor changes when the corn flakes sample contains AFB1 and magnitude of the anodic peak further decreases as the AFB1 concentration increases in the corn flakes sample. The results obtained with this extracted solution in PBS and result from standard PBS within 3-5\% variations show that the developed immunosensor is highly specific to AFB1; it avoids interference of other materials present in corn flakes extracts. 


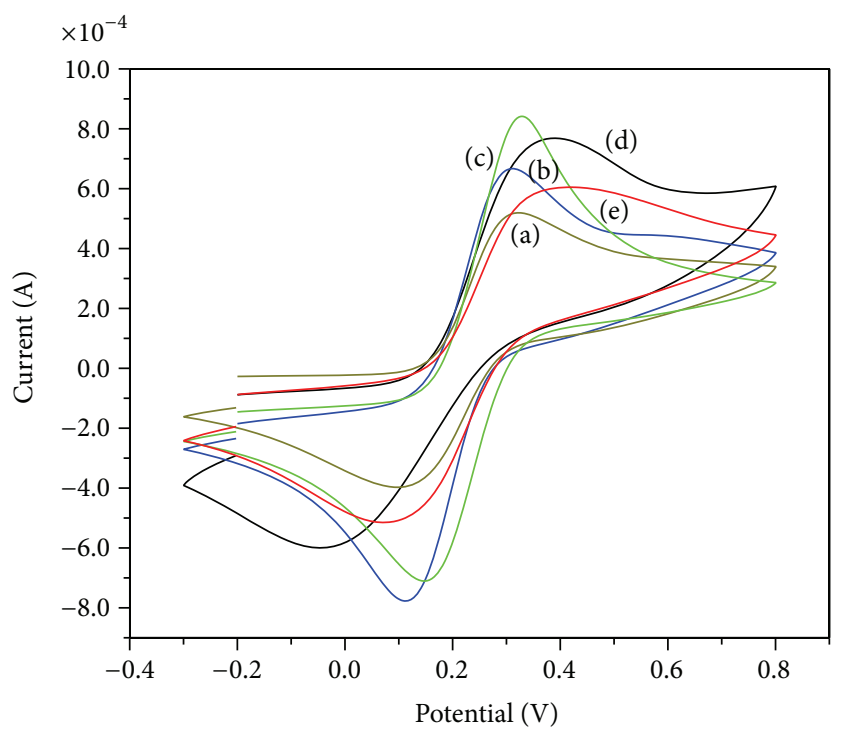

(a)

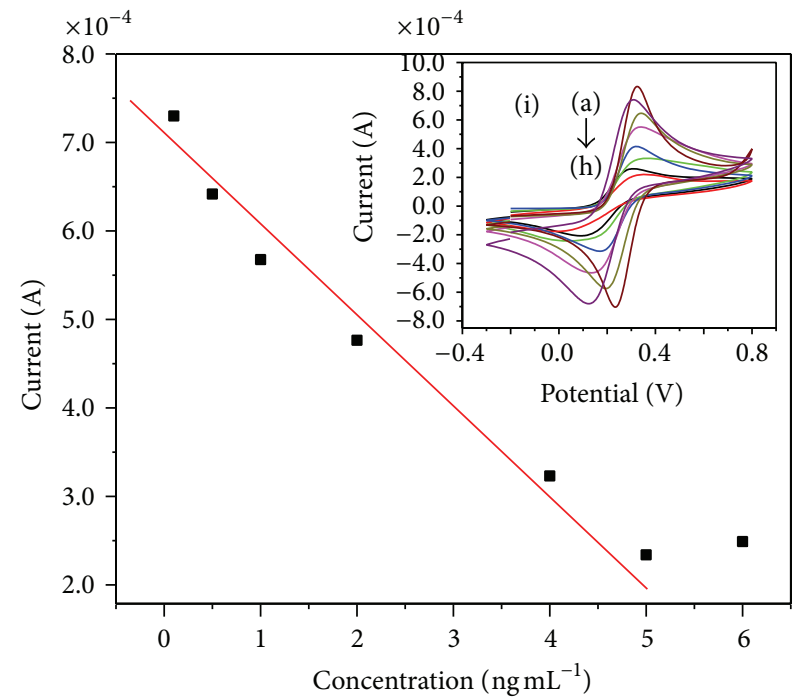

(b)

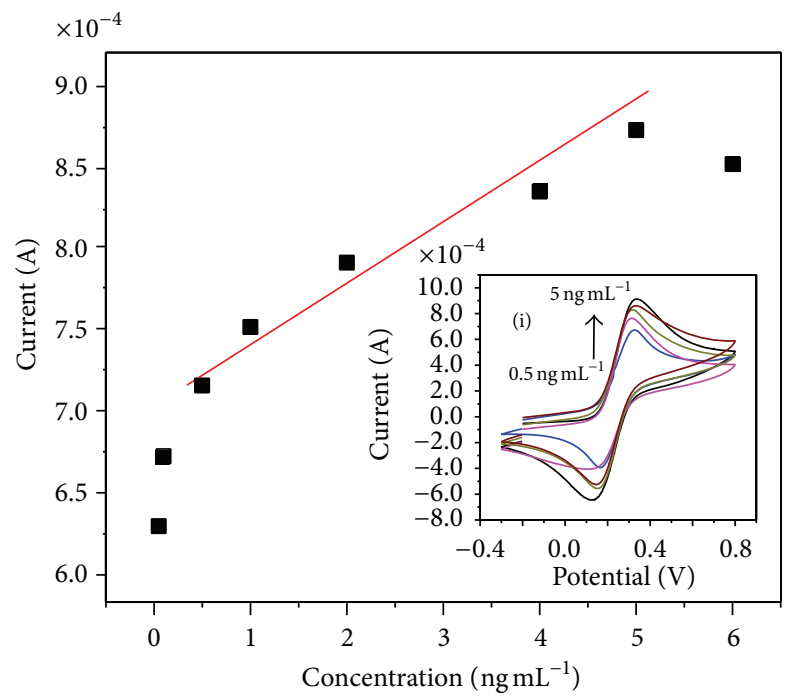

(c)

Figure 7: (a) CV of the AFB1/BSA/aAFB1/4-ATP/Au immunoelectrode with respect to the r-IgG-Cys-Au-Fe $\mathrm{O}_{4}$ concentration: (a) $10 \mu \mathrm{g} \mathrm{mL}^{-1}$, (b) $20 \mu \mathrm{g} \mathrm{mL}^{-1}$, (c) $30 \mu \mathrm{g} \mathrm{mL}{ }^{-1}$, (d) $40 \mu \mathrm{g} \mathrm{mL}^{-1}$, and (e) $50 \mu \mathrm{g} \mathrm{mL}{ }^{-1}$, in PBS $(50 \mathrm{mM}, \mathrm{pH} 7.4,0.9 \% \mathrm{NaCl})$ containing $\left[\mathrm{Fe}(\mathrm{CN})_{6}\right]^{3-/ 4-}$ $(5 \mathrm{mM})$. (b) Calibration curve for competitive detection of AFB1. Inset (b) shows (i) CV of the AFB1/BSA/aAFB1/4-ATP/Au immunoelectrode with respect to the AFB1 concentration (0.05-5 $\mathrm{ng} \mathrm{mL}^{-1}$ ). (c) Calibration curve for noncompetitive detection of AFB1. Inset (c) shows (i) CV of the AFB1/BSA/aAFB1/4-ATP/Au immunoelectrode with respect to the AFB1 concentration $\left(0.5-5 \mathrm{ng} \mathrm{mL}^{-1}\right)$.

3.3.7. Reproducibility, Shelf Life, and Regeneration of Immunoelectrode. The reproducibility of the proposed immunoelectrode was estimated by repetitive measurement of immunoelectrode with current response using $2 \mathrm{ng} \mathrm{mL}^{-1}$ standard AFB1 solutions in PBS $(50 \mathrm{mM}, \mathrm{pH} 7.4,0.9 \% \mathrm{NaCl}$, containing $\left.5 \mathrm{mM}\left[\mathrm{Fe}(\mathrm{CN})_{6}\right]^{3-/ 4-}\right)$. The results obtained in 5 repeated measurements show a relative standard deviation (RSD) of $2-3 \%$, indicating that the obtained data are reproducible. These results demonstrate the acceptable reproducibility and precision of the proposed immunosensor. In addition, the immunosensor could be stored at $4^{\circ} \mathrm{C}$ for shelf life study. The stability of the BSA/aAFB1/4-ATP/Au immunoelectrode was evaluated by EQCM-CV study and the current response in the presence of $2 \mathrm{ng} \mathrm{mL}^{-1}$ standard AFB1 solution in PBS $(50 \mathrm{mM}, \mathrm{pH} 7.4,0.9 \% \mathrm{NaCl})$ was monitored at a regular interval of 7 days (Figure 8(b)). The immunoelectrode retains its activity up to 28 days with $5-7 \%$ decrease in activity. $95 \%$ of the initial response was left remaining after 1 week and $90 \%$ of the initial response was left remaining after 1 month, indicating acceptable stability.

The immunosensor can be regenerated (Scheme 2) using an external strong magnet to remove the immuno-r-IgGCys- $\mathrm{Au}-\mathrm{Fe}_{3} \mathrm{O}_{4}$ conjugate (i.e., r-IgG-Cys- $\mathrm{Au}-\mathrm{Fe}_{3} \mathrm{O}_{4}$ ). It was observed that the reagent-free regeneration method could 

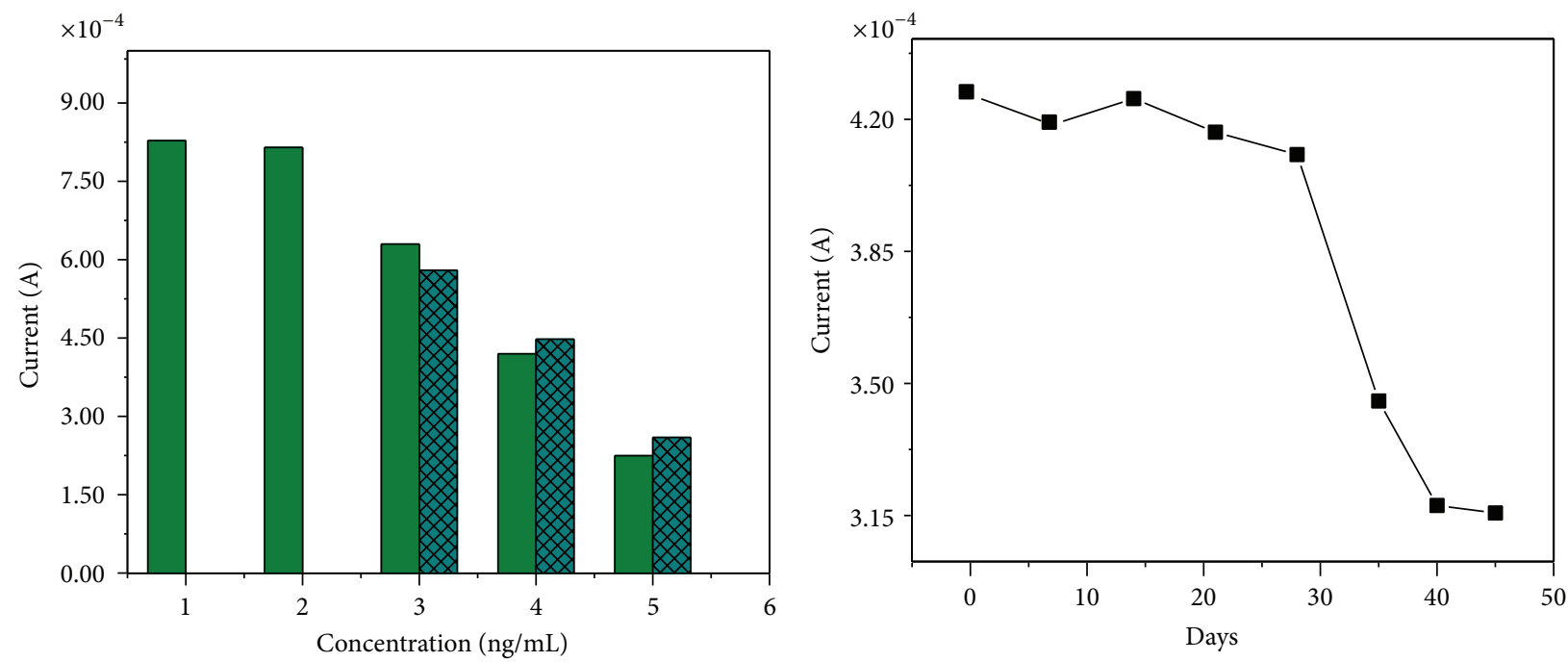
(1) 0 concentration AFB1
(2) Corn extract
(3) Corn extract $+0.05 \mathrm{ng} / \mathrm{mL}$ AFB1
(4) Corn extract $+2 \mathrm{ng} / \mathrm{mL}$ AFB1
(5) Corn extract $+5 \mathrm{ng} / \mathrm{mL}$ AFB1

(a)

(b)

Figure 8: (a) Bar chart of frequency change for corn flakes sample with addition of AFB1 concentration. (b) Shelf life study of immunoelectrode with EQCM-CV at 7-day interval.

regenerate the immunosensor up to $15-16$ times with $2-3 \%$ loss in activity using a fixed concentration of AFB1.

\section{Conclusions}

In the present study, a reusable immunoelectrode is developed using self-assembled 4-ATP on quartz crystal electrode. EQCM measurement technique is applied to determine the response current of sandwiched structure comprising BSA/aAFB1/4-ATP/Au immunoelectrode, AFB1, and r-IgGCys-Au- $\mathrm{Fe}_{3} \mathrm{O}_{4}$. The regeneration of the immunoelectrode is done after removing the AFB1 attached with r-IgG-Cys-Au$\mathrm{Fe}_{3} \mathrm{O}_{4}$ through external magnet. The immunosensor can be regenerated about $15-16$ times with $2-3 \%$ loss of activity. We have compared the competitive and noncompetitive methods for the determination of the AFB1. It has been observed that the competitive mode has offered wider linear range of $0.05-$ $5 \mathrm{ng} \mathrm{mL}^{-1}$ with the limit of detection of $0.07 \mathrm{ng} \mathrm{mL}^{-1}$ and higher sensitivity than the noncompetitive one while coated AFB1 and free AFB1 are identical in chemical structure. This immunosensor is found to be highly promising for detection of AFB1 in corn flakes samples. Therefore, the same principle can be utilized for detection of other food toxins such as OTA, OTB, fumonisins, and zearalenone and other small molecules also.

\section{Conflict of Interests}

The authors declare that there is no conflict of interests regarding the publication of this paper.

\section{Acknowledgments}

The authors thank Dr. Ashok Kumar Chauhan (Founder President, Amity University, Uttar Pradesh) for providing the facilities. They also thank Dr. (Mrs.) Balvinder Shukla, Vice Chancellor, Amity University, Uttar Pradesh, and Professor L. M. Bharadwaj, Director, AINT. The authors also express their deep gratitude to Ms. Shuvra Singha, Department of Chemistry, University of Hyderabad, India, for her help in conducting the XRD studies.

\section{References}

[1] Y. Li, X. Liu, and Z. Lin, "Recent developments and applications of surface plasmon resonance biosensors for the detection of mycotoxins in foodstuffs," Food Chemistry, vol. 132, no. 3, pp. 1549-1554, 2012.

[2] J. W. Bennett and M. Klich, "Mycotoxins," Clinical Microbiology Reviews, vol. 16, no. 3, pp. 497-516, 2003.

[3] R. G. Digigow, J.-F. Dechézelles, H. Dietsch et al., "Preparation and characterization of functional silica hybrid magnetic nanoparticles," Journal of Magnetism and Magnetic Materials, vol. 362, pp. 72-79, 2014.

[4] International Agency for Research on Cancer, IARC Monographs on the Evaluation of Carcinogenic Risks to Humans, vol. 56, IARC, Lyon, France, 1993.

[5] E. Anklam, J. Stroka, and A. Boenke, "Acceptance of analytical methods for implementation of EU legislation with a focus on mycotoxins," Food Control, vol. 13, no. 3, pp. 173-183, 2002.

[6] D. M. Parkin, F. Bray, J. Ferlay, and P. Pisani, "Estimating the world cancer burden: Globocan 2000," International Journal of Cancer, vol. 94, no. 2, pp. 153-156, 2001. 
[7] H. P. Van Egmond, R. C. Schothorst, and M. A. Jonker, "Regulations relating to mycotoxins in food," Analytical and Bioanalytical Chemistry, vol. 389, no. 1, pp. 147-157, 2007.

[8] W. S. Khayoon, B. Saad, B. Salleh, N. H. A. Manaf, and A. A. Latiff, "Micro-solid phase extraction with liquid chromatographytandem mass spectrometry for the determination of aflatoxins in coffee and malt beverage," Food Chemistry, vol. 147, pp. 287294, 2014.

[9] F. Hepsag, O. Golge, and B. Kabak, "Quantitation of aflatoxins in pistachios and groundnuts using HPLC-FLD method," Food Control, vol. 38, no. 1, pp. 75-81, 2014.

[10] O. G. Roch, G. Blunden, R. D. Coker, and S. Nawaz, "The validation of a solid phase clean-up procedure for the analysis of aflatoxins in groundnut cake using HPLC," Food Chemistry, vol. 52, no. 1, pp. 93-98, 1995.

[11] D. W. Kimmel, G. Leblanc, M. E. Meschievitz, and D. E. Cliffel, "Electrochemical sensors and biosensors," Analytical Chemistry, vol. 84, no. 2, pp. 685-707, 2012.

[12] J. C. Vidal, L. Bonel, A. Ezquerra, P. Duato, and J. R. Castillo, "An electrochemical immunosensor for ochratoxin A determination in wines based on a monoclonal antibody and paramagnetic microbeads," Analytical and Bioanalytical Chemistry, vol. 403, no. 6, pp. 1585-1593, 2012.

[13] R. Chauhan, Deepshikha, and T. Basu, "Development of a reusable transducer matrix based on nano structured conducting polyaniline and its application to cholesterol biosensor," Science of Advanced Materials, vol. 4, no. 1, pp. 96-105, 2012.

[14] R. Chauhan, B. Nagar, P. R. Solanki, and T. Basu, "Development of triglyceride biosensor based on a platinum nanoparticle and polypyrrole nano composite electrode," Materials Focus, vol. 2, no. 4, pp. 316-323, 2013.

[15] L. Masoomi, O. Sadeghi, M. H. Banitaba, A. Shahrjerdi, and S. S. H. Davarani, "A non-enzymatic nanomagnetic electroimmunosensor for determination of Aflatoxin B1 as a model antigen," Sensors and Actuators B, vol. 177, pp. 1122-1127, 2013.

[16] S. Srivastava, V. Kumar, M. A. Ali et al., "Electrophoretically deposited reduced graphene oxide platform for food toxin detection," Nanoscale, vol. 5, no. 7, pp. 3043-3051, 2013.

[17] M. Puiu, O. Istrate, L. Rotariu, and C. Bala, "Kinetic approach of aflatoxin B1-acetylcholinesterase interaction: a tool for developing surface plasmon resonance biosensors," Analytical Biochemistry, vol. 421, no. 2, pp. 587-594, 2012.

[18] X. Xu, X. Liu, Y. Li, and Y. Ying, "A simple and rapid optical biosensor for detection of aflatoxin B1 based on competitive dispersion of gold nanorods," Biosensors and Bioelectronics, vol. 47, pp. 361-367, 2013.

[19] T. Li, J.-Y. Byun, B. B. Kim, Y.-B. Shin, and M.-G. Kim, "Labelfree homogeneous FRET immunoassay for the detection of mycotoxins that utilizes quenching of the intrinsic fluorescence of antibodies," Biosensors and Bioelectronics, vol. 42, no. 1, pp. 403-408, 2013.

[20] B. Prieto-Simón, I. Karube, and H. Saiki, "Sensitive detection of ochratoxin A in wine and cereals using fluorescence-based immunosensing," Food Chemistry, vol. 135, no. 3, pp. 1323-1329, 2012.

[21] K. Spinella, L. Mosiello, G. Palleschi, F. Vitali, and K. Spinella, "Development of a QCM (quartz crystal microbalance) biosensor to the detection of aflatoxin B1," Open Journal of Applied Biosensor, vol. 2, no. 4, pp. 112-119, 2013.

[22] J. Li, X. He, Z. Wu, K. Wang, G. Shen, and R. Yu, "Piezoelectric immunosensor based on magnetic nanoparticles with simple immobilization procedures," Analytica Chimica Acta, vol. 481, no. 2, pp. 191-198, 2003.

[23] J. C. Vidal, P. Duato, L. Bonel, and J. R. Castillo, "Use of polyclonal antibodies to ochratoxin A with a quartz-crystal microbalance for developing real-time mycotoxin piezoelectric immunosensors," Analytical and Bioanalytical Chemistry, vol. 394, no. 2, pp. 575-582, 2009.

[24] A. V. Nabok, A. Tsargorodskaya, A. Holloway, N. F. Starodub, and O. Gojster, "Registration of T-2 mycotoxin with total internal reflection ellipsometry and QCM impedance methods," Biosensors and Bioelectronics, vol. 22, no. 6, pp. 885-890, 2007.

[25] C. I. Cheng, Y.-P. Chang, and Y.-H. Chu, "Biomolecular interactions and tools for their recognition: focus on the quartz crystal microbalance and its diverse surface chemistries and applications," Chemical Society Reviews, vol. 41, no. 5, pp. 19471971, 2012.

[26] Y. Zhang, H. Wang, B. Yan et al., "A reusable piezoelectric immunosensor using antibody-adsorbed magnetic nanocomposite," Journal of Immunological Methods, vol. 332, no. 1-2, pp. 103-111, 2008.

[27] Y. Zhuo, P.-X. Yuan, R. Yuan, Y.-Q. Chai, and C.-L. Hong, "Bienzyme functionalized three-layer composite magnetic nanoparticles for electrochemical immunosensors," Biomaterials, vol. 30, no. 12, pp. 2284-2290, 2009.

[28] L. Wang and X.-X. Gan, "Biomolecule-functionalized magnetic nanoparticles for flow-through quartz crystal microbalance immunoassay of aflatoxin B1," Bioprocess and Biosystems Engineering, vol. 32, no. 1, pp. 109-116, 2009.

[29] N. A. Frey, M. H. Phan, H. Srikanth, S. Srinath, C. Wang, and S. Sun, "Interparticle interactions in coupled $\mathrm{Au}-\mathrm{Fe}_{3} \mathrm{O}_{4}$ nanoparticles," Journal of Applied Physics, vol. 105, no. 7, Article ID 07B502, 2009.

[30] R. Costi, A. E. Saunders, and U. Banin, "Colloidal hybrid nanostructures: a new type of functional materials," Angewandte Chemie International Edition, vol. 49, no. 29, pp. 4878-4897, 2010.

[31] X. Jin, X. Jin, L. Chen, J. Jiang, G. Shen, and R. Yu, "Piezoelectric immunosensor with gold nanoparticles enhanced competitive immunoreaction technique for quantification of aflatoxin B1," Biosensors and Bioelectronics, vol. 24, no. 8, pp. 2580-2585, 2009.

[32] X. Jin, X. Jin, X. Liu et al., "Biocatalyzed deposition amplification for detection of aflatoxin B1 based on quartz crystal microbalance," Analytica Chimica Acta, vol. 645, no. 1-2, pp. 92-97, 2009.

[33] S. Banerjee, S. O. Raja, M. Sardar, N. Gayathri, B. Ghosh, and A. Dasgupta, "Iron oxide nanoparticles coated with gold: enhanced magnetic moment due to interfacial effects," Journal of Applied Physics, vol. 109, no. 12, Article ID 123902, 2011.

[34] A. Sharma, Z. Matharu, G. Sumana, P. R. Solanki, C. G. Kim, and B. D. Malhotra, "Antibody immobilized cysteamine functionalized-gold nanoparticles for aflatoxin detection," Thin Solid Films, vol. 519, no. 3, pp. 1213-1218, 2010.

[35] R. Chauhan, P. R. Solanki, J. Singh, I. Mukherjee, T. Basu, and B. D. Malhotra, "A novel electrochemical piezoelectric label free immunosensor for aflatoxin B1 detection in groundnut," Food Control, vol. 52, pp. 60-70, 2015.

[36] B. Prieto-Simón, M. Campàs, J.-L. Marty, and T. Noguer, "Novel highly-performing immunosensor-based strategy for ochratoxin A detection in wine samples," Biosensors and Bioelectronics, vol. 23, no. 7, pp. 995-1002, 2008.

[37] J. Singh, P. Khanra, T. Kuila et al., "Preparation of sulfonated poly(ether-ether-ketone) functionalized ternary 
graphene/AuNPs/chitosan nanocomposite for efficient glucose biosensor," Process Biochemistry, vol. 48, no. 11, pp. 1724-1735, 2013.

[38] S. Pal, M. Morales, P. Mukherjee, and H. Srikanth, "Synthesis and magnetic properties of gold coated iron oxide nanoparticles," Journal of Applied Physics, vol. 105, no. 7, Article ID 07B504, 2009.

[39] I. Robinson, L. D. Tung, S. Maenosono, C. Wälti, and N. T. K. Thanh, "Synthesis of core-shell gold coated magnetic nanoparticles and their interaction with thiolated DNA," Nanoscale, vol. 2, no. 12, pp. 2624-2630, 2010.

[40] C. Zhang, S. Si, and Z. Yang, "A highly selective photoelectrochemical biosensor for uric acid based on core-shell $\mathrm{Fe}_{3} \mathrm{O}_{4} @ \mathrm{C}$ nanoparticle and molecularly imprinted $\mathrm{TiO}_{2}$," Biosensors and Bioelectronics, vol. 65, pp. 115-120, 2015.

[41] M. B. Young, B.-K. Oh, W. Lee, H. L. Won, and J.-W. Choi, "Study on orientation of immunoglobulin G on protein G layer," Biosensors and Bioelectronics, vol. 21, no. 1, pp. 103-110, 2005.

[42] M. Hegner, P. Wagner, and G. Semenza, "Ultralarge atomically flat template-stripped $\mathrm{Au}$ surfaces for scanning probe microscopy," Surface Science, vol. 291, no. 1-2, pp. 39-46, 1993.

[43] P. R. Solanki, A. Kaushik, T. Manaka et al., "Self-assembled monolayer based impedimetric platform for food borne mycotoxin detection," Nanoscale, vol. 2, no. 12, pp. 2811-2817, 2010. 

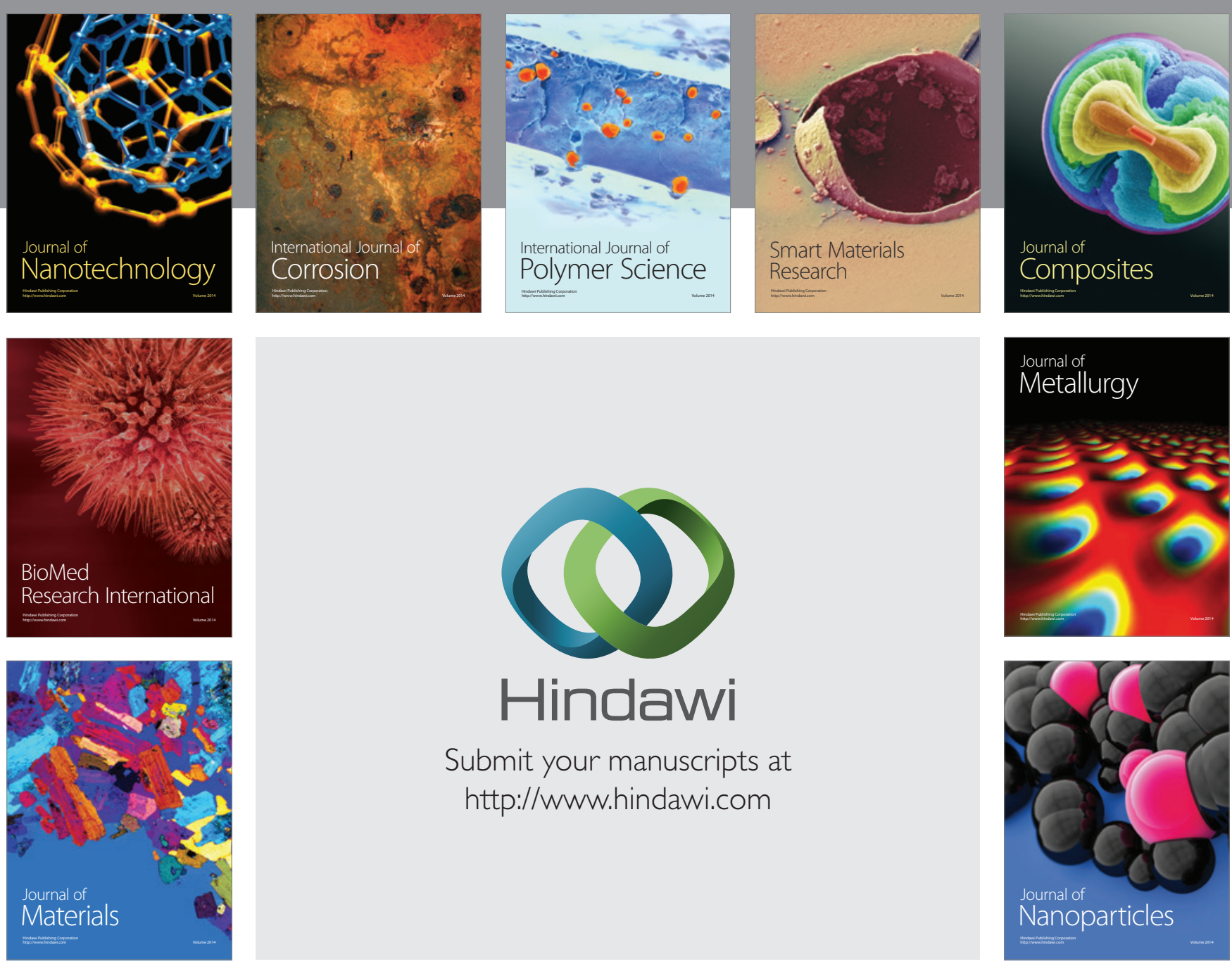

Submit your manuscripts at http://www.hindawi.com
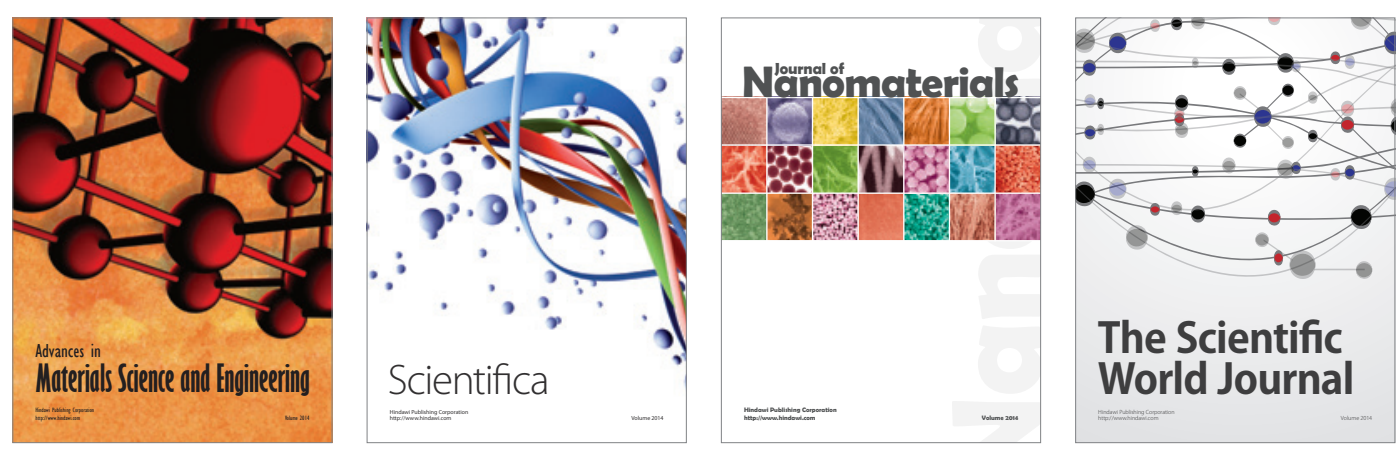

\section{The Scientific World Journal}
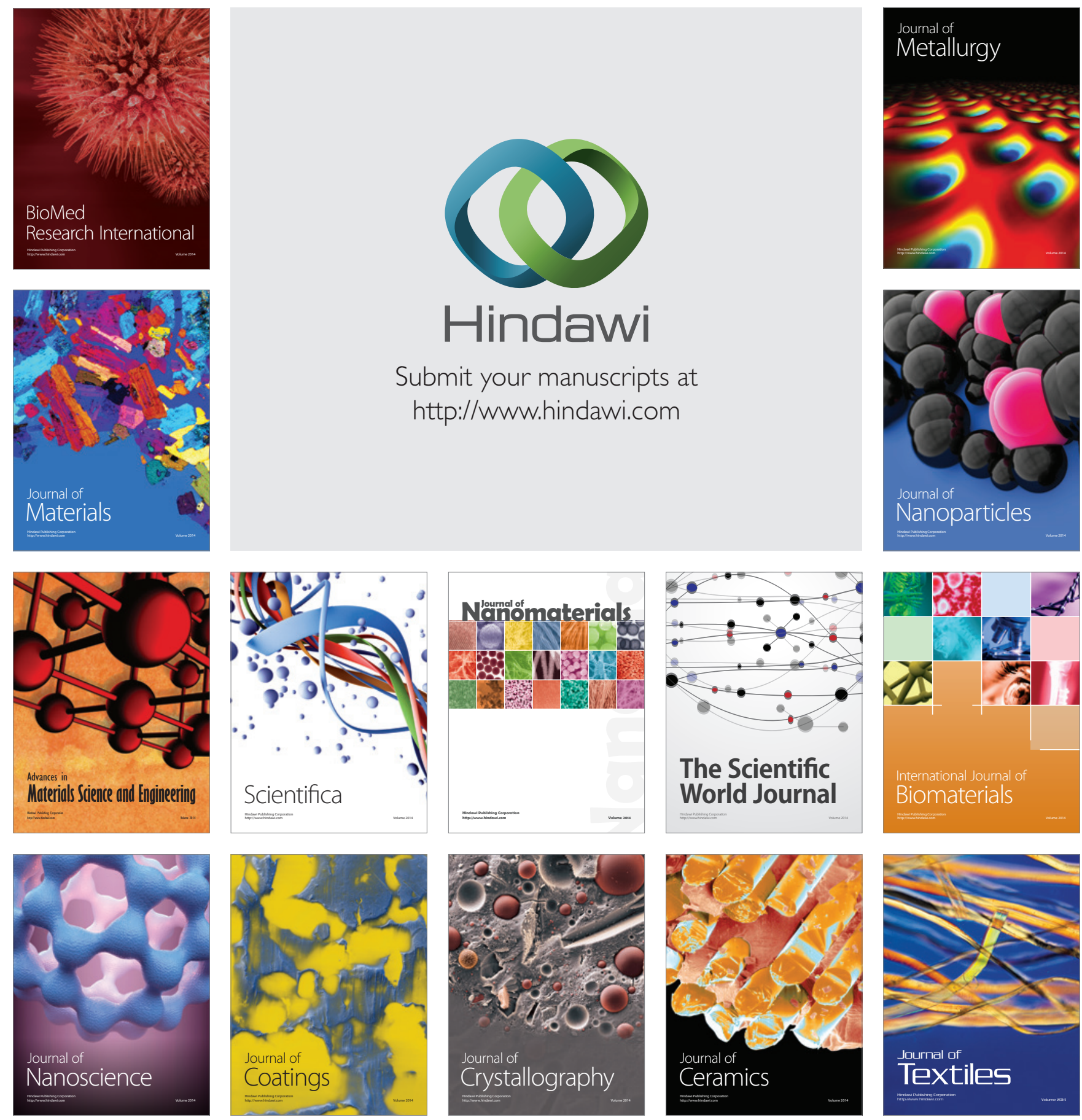